\title{
Ecology and niche assembly of Campanula tommasiniana, a narrow endemic of Mt Učka (Liburnian karst, north-western Adriatic)
}

\author{
BoŠTJAN SURINA ${ }^{1,2^{*}}$, ANDREJ MARTINČIČ ${ }^{3}$ \\ ${ }^{1}$ Faculty of Mathematics, Natural Sciences and Information Technologies, \\ University of Primorska, Glagoljaška 8, SI-6000 Koper, Slovenia \\ ${ }^{2}$ Natural History Museum Rijeka, Lorenzov prolaz 1, 51000 Rijeka, Croatia \\ ${ }^{3}$ Zaloška cesta 78a, SI-1000 Ljubljana, Slovenia
}

\begin{abstract}
Campanula tommasiniana is a typical chasmophyte occupying calcareous rock crevices and cracks along a wide range of ecological gradients, demonstrating a high degree of ecological plasticity and stress tolerance with regards to abiotic factors. Generally, three ecologically and floristically distinct groups of stands were recognized and typified according to a sigmatistic approach: (a) Seslerio juncifoliae-Campanuletum tommasinianae ass. nov., with stands occupying higher elevated sites fully exposed to sun and strong winds; (b) Seslerio autumnalis-Campanuletum tommasinianae ass. nov., representing stands predominantly developed within thermophytic beech stands, semi- to fully-shaded by the tree canopy; (c) Cystopteri fragilis-Campanuletum tommasinianae, sciophytic, stands adapted to moisture and cold with high frequency and coverage of bryophytes. Results of DCA analyses using a unimodal model suggest that Campanula tommasiniana is primarily a plant of open and exposed sites of higher elevation despite being most frequently found in rock crevices within thermophytic and altimontane beech forests.
\end{abstract}

Key words: Campanula tommasiniana, Campanulaceae, Dinaric Alps, ecology, endemic species, Liburnian karst, Mt. Učka, phytosociology

\section{Introduction}

The kaleidoscopic complexity of topographic, climatic and geological conditions in the Mediterranean results in a high degree of overall biodiversity and a rapid species turnover. The flora of the Mediterranean is, for example, the species-richest area in the Old World. Although the Mediterranean region represents less than $1.5 \%$ of the land area of the world, its flora comprises around 30,000 species and subspecies of flowering plants (QUEZÉL 1985, GREUTER 1991), more than 160 species of ferns, and hosts approximately $10 \%$ of all known species of ferns and flowering plants on Earth (BLONDEL and ARONSON 1999). Around 80\%

\footnotetext{
* Corresponding author, e-mail: bostjan.surina@prirodoslovni.com

Copyright $^{\circledR} 2014$ by Acta Botanica Croatica, the Faculty of Science, University of Zagreb. All rights reserved.
} 
of all endemic taxa are to be found in the area (GoMEZ-CAMPO 1985). However, the main reason for such a high degree of biodiversity of flowering plants in Mediterranean is not the overall species richness of the area, but the high number of endemics, many of them restricted to one or only a few known localities with specifics in ecology (e.g., geology, soil type, relief, etc.) or geography (e.g., islands, mountains). Here, almost every island, regardless of its size, hosts at least some (indigenous) endemic taxa. Ecologically similar to islands, mountains promote speciation events too, which may result in there being up to $42 \%$ of endemics among the higher plants (MEDAIL and VERLAQUE 1997), although this rate may vary a lot (BLONDEL and ARONSON 1999).

One of the many local or regional endemics of the genus Campanula along the Adriatic coast (for the review see KOVAČIĆ 2004, PARK et al. 2006) is the chasmophytic C. tommasiniana Koch (in F. Schultz, Arch. Fl. Fr. et Allemagne 6. Cent., 229, 1852), a narrow endemic of Mt. Učka, located above Kvarner Bay in the Liburnian karst (north-western Adriatic). Along with Edraianthus wettsteinii subsp. lovcenicus and E. dinaricus (Campanulaceae), two narrow endemics of Mt Lovćen, above Kotor Bay, and Mt Mosor in central Dalmatia (WETTSTEIN 1887, JANCHEN 1910, MAYER and BLEČIĆ 1969, LAKUŠIĆ et al. 2009), respectively, and a few predominantly island populations of ambiguous taxonomic rank, e.g., Centaurea friderici, C. kartschiana, C. cuspidata (Asteraceae; e.g., TEYBER 1913, GinZBERGER and TEYBer 1921, GinZBERGER 1921, Lovrić 1971, RAdić 1981, Lovrić 1992), Brassica incana (Brassicaceae; e.g., GINZBERGER 1921) and Asperula staliana (Rubiaceae; e.g., KoriCa 1975, Lovrić and KoriCA 1981, KorICA 1986) aggregates in north-western Adriatic and Dalmatia, C. tommasiniana is one of the most range-restricted taxa among the all adriatide (sensu TROTTER 1912), occupying an area of only $6.5 \mathrm{~km}^{2}$ (SURINA 2013).

The data on ecology and niche assembly of Campanula tommasiniana, despite its being a prominent narrow endemic, are surprisingly scarce. According to HoRvATIĆ (1963b), $C$. tommasiniana is a chasmophyte growing in calcareous rock crevices within thermophytic beech forests of the association Seslerio autumnalis-Fagetum, building an association Campanuletum tommasinianae-justinianae. However, results of a detailed survey of its distribution range and habitat preferences (SURINA 2013) suggest its great ecological plasticity, for it thrives in rock crevices of rocky outcrops and cliffs as well as within various types of forest stands (e.g., associations Fraxino orni-Quercetum ilicis, Querco-Carpinetum orientalis, Aristolochio luteae-Quercetum pubescentis, Seslerio autumnalis-Ostryetum, Seslerio autumnalis-Fagetum and Ranunculo platanifolii-Fagetum) along the whole elevational (vegetational) profile of the mountain's eastern slopes (for detailed comments on vegetation profiles see ŠUGAR 1970, 1984). On western slopes, in contrast to the eastern, it rarely descends below $1000 \mathrm{~m}$ a.s.l. While commenting on the site ecology of Leontopodium alpinum on Mt. Učka, C. tommasiniana (as C. waldsteiniana!) has been recorded within the alliance Micromerion croaticae (ŠUGAR 1971).

With our research we aimed to get insights into site ecology, habitat preferences and niche assembly of Campanula tommasiniana.

\section{Research area}

The Učka mountain range rises above Kvarner Bay; between the Poklon pass (920 m a.s.l.) and Plomin Bay it forms a distinct ridge in a north-south direction along the north-eastern Istrian coast (NE Adriatic). The mountain's highest peaks, Vojak (1396 m 
a.s.1.), Suhi vrh (1332 $\mathrm{m}$ a.s.1.) and Plas (1285 $\mathrm{m}$ a.s.1.), are located in its northern part, which is generally much higher than its southern part. While the macrorelief of the mountain is rather simple, characterized by a prominent ridge, forming distinct eastern and western slopes of the mountain, the microrelief is diversified, being the most picturesque with the solitary limestone towers and cliffs in the Vela draga canyon and beyond the peak Plas on the mountain's western slopes. Some precipitous rock faces are to be found on the eastern slopes as well; the most distinct are those located north of the Grdi breg slope, east of Vojak peak, the eastern rock face of the Suhi vrh peak and the south-western rock face of Argun peak. According to geological maps (ŠIKIĆ et al. 1963, ŠIKIĆ et al. 1967) and explanatory texts (ŠIKIĆ and PoLŠAK 1973, ŠIKIĆ and PlENIČAR 1975), Lower and Upper Cretaceous limestones and dolomites prevail in the area. Along the Lovranska draga valley, limestones and dolomites are intercepted by Quaternary sediments, marlstones and sandstones, conglomerates, breccias and foraminiferan limestones. As indicated by various but pronounced climatogenic vegetation types along an elevational gradient of the mountain, the climate is diverse. The foothills are rather warm with mean annual temperatures between $14-15^{\circ} \mathrm{C}$, while the values gradually decrease with increasing elevation, being only $4-6{ }^{\circ} \mathrm{C}$ at the summits (ZANiNOVIĆ 2008). The higher elevations of the mountain receive from 2000 to $2500 \mathrm{~mm}$ of precipitation yearly, which is the highest amount of precipitation in Istria (GAJIČ-ČAPKA et al. 2008). However, despite being positioned on the Adriatic coast, the eastern foothills of the mountain receive still more than $1500 \mathrm{~mm}$ of precipitation yearly (ibid.). The precipitation regime is a Mediterranean one.

Mt. Učka is one of the most renowned botanical sites in the Adriatic area (TopIć et al. 2009) with a remarkable tradition of botanical exploration (e.g., BRANA 2012, TRINAJSTIĆ and PAVLETIĆ 2012). As a consequence, the mountain's flora is rather well known, although the data on vegetation are somewhat scarce. From a biogeographical aspect and according to ŠUGAR (1970, 1984, but with phytosociological nomenclature according to VUKELIĆ 2012), vegetation types along an elevational profile of the mountain belong to two phytogeographical regions: (a) Mediterranean, further divided into eumediterranean (ass. Fraxino orni-Quercetum ilicis), submediterranean (ass. Querco-Carpinetum orientalis), both restricted to a narrow elevational belt on the mountain's foothills, and epimediterranean (ass. Aristolochio luteae-Quercetum pubescentis) zones, and (b) Eurosibiric-Northamerican region, with paramediterranean (ass. Seslerio autumnalis-Fagetum) and illyric (altimontane beech forests, ass. Ranunculo platanifolii-Fagetum) zones, both covering majority of the mountain range. Within eumediterranean and submediterranean subzones, stands with dominating Laurus nobilis in a tree layer (Fraxino orni-Quercetum ilicis fac. Laurus nobilis and Querco-Carpinetum orientalis lauretosum nobilis) are well developed locally on deeper and moister soils (HoRvaTić 1963a, PELCER 1983). In comparison to other eastern Adriatic mountain ranges of the Dinaric Alps, the outstanding features of Mt. Učka are the homogenous and extensive forests both from the inland (western) and seaward (eastern) sides. Since 1999, the natural and cultural heritage of the area has been protected within Učka Nature Park (NARODNE NOVINE 1999).

\section{Materials and methods}

In summer 2011, we recorded 112 relevés with Campanula tommasiniana through the whole distribution range of the species. The cover-abundance estimates were made accord- 
ing to the Domin scale (sensu DAHL and HADAČ 1941) and the plot size used for sampling averaged $9 \mathrm{~m}^{2}$ (the standard plot size for chasmophytic and scree stands, but see also CHYTRY and OTÝPKOVÁ 2003). Details of the phytosociological parameters of sites are given in Appendix 1 to On-line Supplement Tabs. 2-4. With each relevé, light conditions were roughly estimated as: open sites (no shading), semi-open sites (medium shading) and fully covered sites (full shading) by the canopy of the nearby forest vegetation. A complete floristic inventory is given in table 4, while taxa occurring only once in the analyses are listed in Appendix 2 to On-line Supplement Tabs. 2-4. The nomenclature and taxonomic source for the names of vascular plants was Flora Europaea (TUTIN et al. 2001), while the names of bryophytes were in agreement with the Catalogue of Mosses of Slovenia (MARTINČIČ 2003) and the Annotated Checklist of Slovenian Liverworts and Hornworts (MARTINČIČ 2011). All collected and identified bryophytes are stored in the herbarium of the Natural History Museum Rijeka (NHMR). Raunkiær's life forms (RAUNKIAER 1907), subsequently revised and modified by MüLLER-DOMBOIS and ELLENBERG (1974), were adopted from PignATti (2005) for vascular plants and HiLl and PRESTON (1998), DüLl et al. (1999) and MARTINČIČ $(1966,2003)$ for the bryophytes. Syntaxonomic groups in Tab. 4 were assigned primarily according to Flora alpina (AESCHIMANN et al. 2004), while in some cases we followed our own criteria. Coverage index ( $D_{\%}$, e.g. SuRINA 2005) was calculated for life forms (Tab. 1) and each taxon (Tab. 4), respectively. Prior to numerical analysis, the original cover-abundance values for individual taxa were transformed accordingly (CURRAL 1987). Groups of vegetation types were ascertained using cluster and ordination analyses with the help of the programme package PAST (HAMMER et al. 2001). The arrangement of relevés was done according to the results of cluster analysis and diagnostic groups of species were tested by means of the SIMPER analysis (On-line Supplement Tabs. 1-4), an algorithm implemented in the programme package PAST, and constrained ordination analyses using species fit (of $25 \%$ ) as an inclusion rule, characterized as the quality of the description of the »behaviour « of species values, derived from the particular combination of ordination axes (LEPŠ and ŠMILAUER 2003). In order to explain the variation in niche assembly by specific environmental and structural (phytosociological) parameters, unconstrained (DCA) and constrained (RDA, CCA) ordination analyses were performed, using the CANOCO computer programme (BRAAK TER and ŠMILAUER 2002). In order to determine the lengths of gradients, DCA analyses, detrended by segments, were initially performed and the models (linear, unimodal) used accordingly. The statistical significance $(\mathrm{p}<0.02)$ of the site parameters was tested using the Monte Carlo test, with 499 permutations. Only the significant parameters were then analyzed together, with the aim of producing a general view of the environmental impact on floristic composition and structure of stands. For estimating the general environmental affinities of the relevés, indicator values (co-variables) for vascular plants were assigned according to PIGNATTI (2005) and passively projected into the ordination diagrams. The environmental value in a relevé $\left(\mathrm{EV}_{\mathrm{w}}\right)$ was estimated as the weighted average of the indicator values of all present species, their abundances being used as weights (LEPŠ and ŠMILAUER 2003). The Kruskal-Wallis non-parametric test was used to test whether samples were taken from groups with equal median environmental values and a post-hoc test was carried out using Mann-Whitney's pairwise comparisons. While defining the syntaxa we followed the sigmatistic-Braun-Blanquet approach (BRAUN-BLANQUET 1928), subsequently improved by WESTHOFF and VAN DER MAAREL (1973), and based on a revised association concept proposed by WILLNER (2006). 


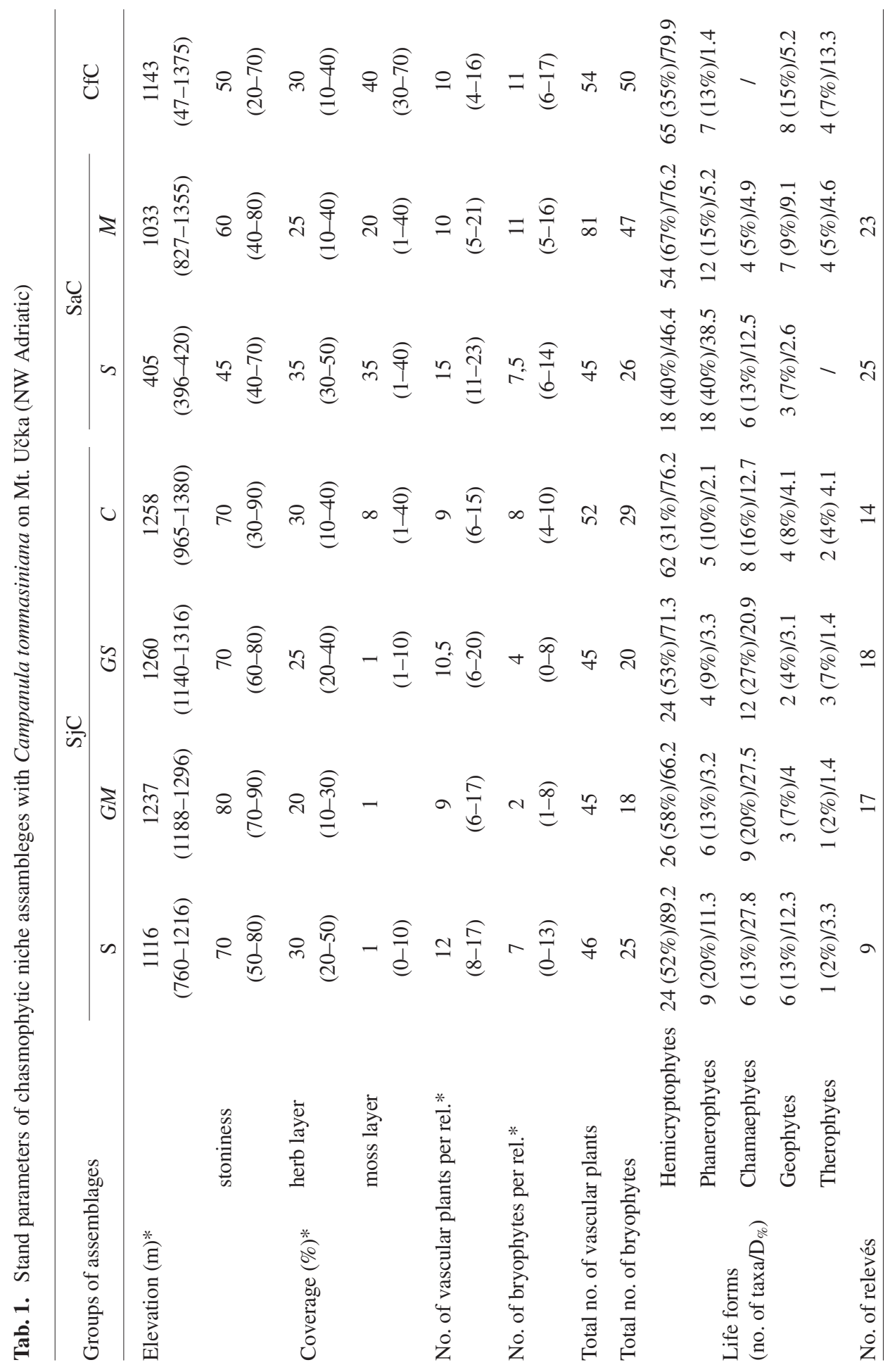


Tab. 2. Overall average dissimilarities (lower left hand corners) and taxa contribution (up to $50 \%$ of overall dissimilarities, upper right hand corners) between the three general types of chasmophytic niche assemblages with Campanula tommasiniana on Mt Učka (NW Adriatic) according to SIMPER analysis. Taxa abbreviations as in table 4 and text below. Syntaxa are explained in the text following figure 3.

\begin{tabular}{|c|c|c|c|}
\hline Syntaxa & $\mathrm{SjC}$ & CfC & $\mathrm{SaC}$ \\
\hline $\mathrm{SjC}$ & & $\begin{array}{l}\text { Nec cri (5.5), Cte mol (4.6), Ses jun } \\
\text { (3.6), Asp tri (2.5), Cys fra (2.3), Cym } \\
\text { mur (2.1), Pla str, Hom phy, Myc mur, } \\
\text { Cam tom (2), Ath tur (1.7), Glo cor, } \\
\text { Rad com (1.4), Tor tor, Sil sax, Sch sp, } \\
\text { Asp rtm (1.3), Hom ser, Ara alp (1.2) }\end{array}$ & $\begin{array}{l}\text { Ses jun (4), Nec cri (2.8), Ano vit (2.5), } \\
\text { Pla str (2.3), Hom ser (2.2), Asp tri, } \\
\text { Cam tom (2), Nec bes, Cte mol (1.9), } \\
\text { Ses aut (1.8), Ath tur, Hom phi (1.7), } \\
\text { Glo cor, Sch sp, Asp rtm (1.5), Tor tor, } \\
\text { Sil sax (1.4), Mic thy, Por pla, Nec com } \\
\text { (1.2), Sat mon (1.1), Cyc pur (1) }\end{array}$ \\
\hline $\mathrm{CfC}$ & 80.44 & & $\begin{array}{l}\text { Nec cri (3.1), Cte mol (2.8), Ano vit } \\
\text { (2), Cys fra (1.8), Hom ser (1.7), Pla } \\
\text { str, Cym mur, Hom phi (1.6), Nec bes } \\
\text { (1.5), Ses aut, Cam tom, Myc mur } \\
\text { (1.3), Asp rtm, Tor tor (1.2), Rad com, } \\
\text { Sch sp, Pse alb, Nec com (1.1), Por pla, } \\
\text { Asp tri, Ara alp, Fis dub, Cyc pur (1) }\end{array}$ \\
\hline $\mathrm{SaC}$ & 78.63 & 65.92 & \\
\hline
\end{tabular}

\section{Results}

\section{Niche selection and floristic assembly of stands}

Campanula tommasiniana, inhabiting calcareous rock crevices and cracks from low elevated sites $(47 \mathrm{~m})$ to mountain tops $(1390 \mathrm{~m})$, is an edificatory vascular plant for chasmophytic assemblages. The total floristic assembly of stands, covering $10-80 \%(\mathrm{Me}=35 \%)$ of the sampling plots, counts for 155 taxa of vascular plants and 77 taxa of bryophytes (two of them are lichenicolous fungi), with a median number of $12(\min =6, \max =23)$ and 8 $(\min =0, \max =17)$ taxa per plot, respectively (Tab. 4, On-line Supplement Tabs. 2-4). The coverage and number of taxa of vascular plants and bryophytes varies a lot between the sites (Tab. 1) and depends heavily on site ecology. Among the vascular plants, typical chasmophytes occur in more than one third of the relevés: Campanula tommasiniana (100\%), Asplenium ruta-muraria (71), A. trichomanes (65), Sesleria juncifolia (57), Athamanta turbith (46) and Cymbalaria muralis (40), while among bryophytes the most frequent were Tortella tortuosa (71), Ctenidium molluscum (54), Schistidium sp. (54), Neckera crispa (51), Homalothecium sericeum (50), H. philippeanum (36) and Plasteurhynchium striatulum (35; Tab. 4). In number and coverage of vascular plant taxa, hemicryptophytes completely prevail and represent more than a half of all registered vascular plant taxa $\left(\mathrm{D}_{\%}=46.4-\right.$ 89.2), followed by phanerophytes $\left(18 \%, \mathrm{D}_{\%}=1.4-38.5\right)$, geophytes $(15 \%, \mathrm{D} \%=2.6-12.3)$, therophytes $(5 \%, \mathrm{D} \%=0-13.3)$ and chamaephytes $(3 \%, \mathrm{D} \%=0-27.8)$.

\section{Cluster and SIMPER analyses}

Application of various algorithms and (dis)similarity measures yields very similar clustering topology. A dendrogram of chasmophytic stands from Mt. Učka shows two 
groups of relevés (Fig. 1). In cluster »A«, 97 taxa of vascular plants, 34 taxa of bryophytes and 2 taxa of lichenicolous fungi are surveyed. Beside Campanula tommasiniana $^{2-5}(100 \%)$, Sesleria juncifolia ${ }^{3-6}(90)$, Asplenium ruta-muraria ${ }^{+-3}(71)$ and Athamanta turbith ${ }^{+-6}(69)$ completely prevail (Tab. 4, On-line Supplement Tabs. 2-4). Other relatively frequent vascular plants are Silene saxifraga subsp. hayekiana ${ }^{+-3}(55)$, Micromeria thymifolia $^{1-3}(48)$, Asplenium trichomanes $^{1-4}(40)$ and Scrophularia laciniata ${ }^{+-3}(36)$. The most frequent bryo-

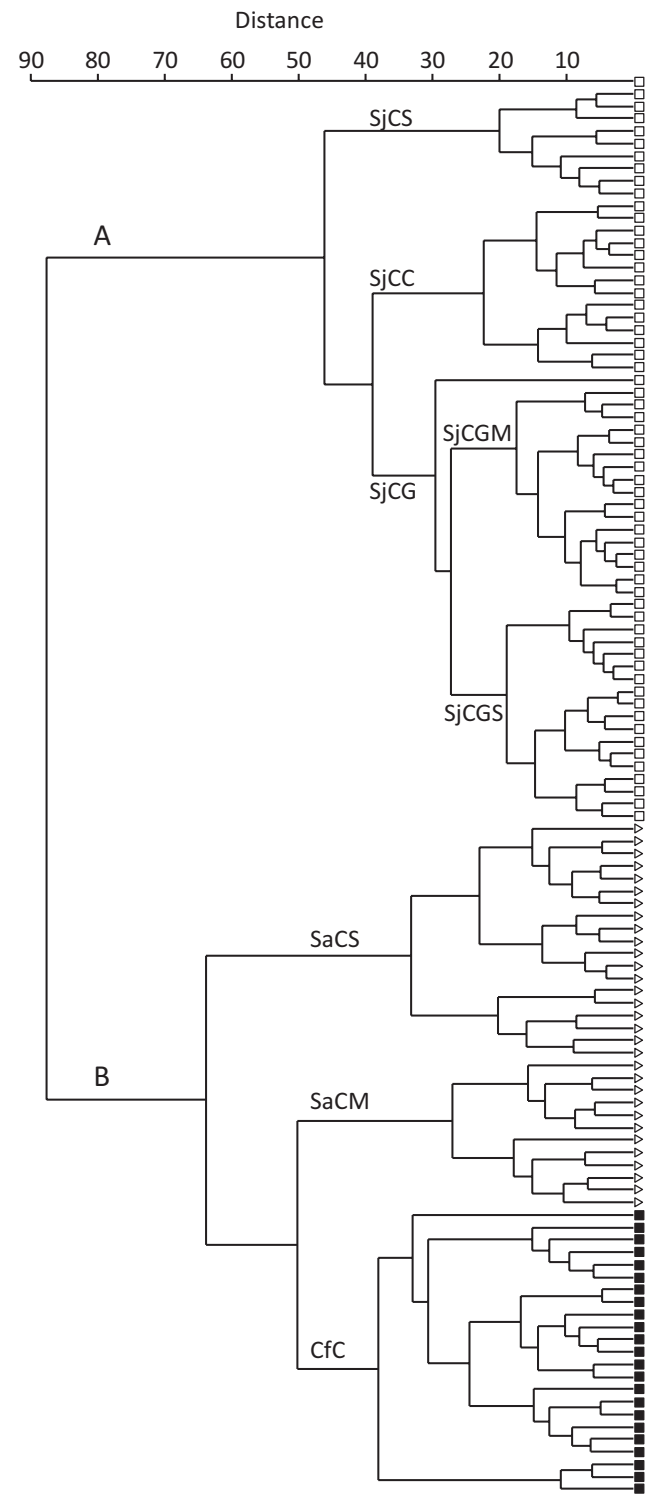

Fig. 1. Dendrogram of chasmophytic assemblages with Campanula tommasiniana on Mt. Učka (NW Adriatic; Ward's method, Euclidean distances). Syntaxonomy is explained in the text following figure 3 . 
phytes are Tortella tortuosa $a^{1-3}(79)$, Schistidium sp. ${ }^{1-3}(45)$ and Homalothecium serice$u^{1-3}(38)$. In cluster $» \mathrm{~A} «$ the following taxa occur exclusively: Globularia cordifolia ${ }^{2-4}(57)$, Senecio abrotanifolius ${ }^{1-3}(29)$, Stachys subcrenata ${ }^{1-3}(26)$, Arabis scopoliana ${ }^{1-3}(19)$, Sempervivum tectorum $^{+-3}(16)$, Rosa pimpinellifolia ${ }^{+-2}(14 \%)$, Euphrasia illyrica ${ }^{+-3}(12)$, Cam- $^{-}$ panula marchesettii ${ }^{1-3}(10)$, C. cochleariifolia ${ }^{+2}(10)$, Rhamnus saxatilis ${ }^{1-3}(9)$, Gentiana lutea subsp. symphyandra ${ }^{+-2}(9)$, Teucrium arduinii $^{1-4}(9)$, Satureja subspicata subsp. liburnica $^{+-2}(7)$, Primula auricula ${ }^{1-4}(5)$, Leontopodium alpinum ${ }^{1-2}(5)$ and others, while Silene saxifraga subsp. hayekiana, Sedum album ${ }^{1-3}(16)$, Micromeria thymifolia, Hieracium bupleuroides $^{1-3}(31)$, Scrophularia laciniata, Allium saxatile subsp. tergestinum ${ }^{+-3}(24)$, Teu- $^{-}$ crium montanum $^{+-3}(24)$, Saxifraga paniculata ${ }^{1-3}(16)$ occur almost exclusively. Bryophytes, found relatively frequently only in this cluster, are Tortella densa ${ }^{2-3}(10)$, Ditrichium flexicaule $^{2-3}(17)$, while Syntrichia ruralis var. ruralis $^{1-3}(16)$ and Scapania $\operatorname{aspera~}^{1-3}(7)$ occur in cluster $» \mathrm{~A}$ « almost exclusively. Cluster $» \mathrm{~A} «$ further divides into three sub-clusters: (a) SjCG (On-line Supplement Tab. 2, rel. 10-44) is characterized by high frequency and coverage of Globularia cordifolia ${ }^{2-4}(89)$ and Hieracium bupleuroides ${ }^{1-3}(43)$, and the two groups of stands: Micromeria thymifolia ${ }^{2-3}(94)$, Scrophularia laciniata ${ }^{+-3}$ (56; SjCGM) and Stachys subcrenata ${ }^{1-3}(59)$, Tortella densa ${ }^{2-3}$ (35; SjCGS), respectively (rel. 10-27, 28-44 in On-line Supplement Tab. 2); (b) SjCC (On-line Supplement Tab. 2, rel. 45-58), characterized by high constancy, frequency and coverage of bryophytes, specially Ctenidium molluscum $^{1-4}(93)$, Neckera crispa ${ }^{1-4}(36)$ and Fissidens dubius ${ }^{1-3}(43)$; (c) SjCS (On-line Supplement Tab. 2, rel. 1-9), where Sedum album ${ }^{1-3}(89)$, Satureja montana subsp. variegata $^{3-5}(67)$ and Syntrichia ruralis var. ruralis ${ }^{1-3}(56)$ occur almost exclusively.

Cluster $\gg \mathrm{B}$ « represents less homogenous but more diverse floristic assembly; a total of 130 taxa of vascular plants and 56 taxa of bryophytes are registered. Along the Campanula tommasiniana $^{2-6}(100)$, the most frequent vascular plants are: Asplenium trichomanes ${ }^{2-5}$ (100), A. ruta-muraria ${ }^{2-4}(96)$, Cymbalaria muralis ${ }^{2-4}(91)$, Mycelis muralis $^{+-3}$ (87), Cystopteris fragilis $^{2-4}(83)$, Geranium robertianum ${ }^{1-3}$ (57), Plagiochilla porelloides ${ }^{1-3}(43)$, Cycla- $^{-3}$ men purpurascens ${ }^{2-3}(39)$, Valeriana tripteris ${ }^{1-3}(39)$, Senecio fuchsii ${ }^{+-3}(35)$, Pseudofumaria alba $^{1-7}(30)$, Saxifraga rotundifolia ${ }^{2-4}(30)$, Adenostyles glabra ${ }^{1-3}(30)$, Sesleria juncifolia ${ }^{+-3}$ (30). In comparison to cluster $» A \ll$, bryophytes are much more frequent and abundant in cluster $\gg \mathrm{B} \ll$. The most common taxa are Ctenidium molluscum ${ }^{3-8}(100)$, Neckera crispa $^{3-8}$ (96), Schistidium sp. ${ }^{1-3}(65)$, Homalothecium philippeanum ${ }^{3-5}(57)$, Plasteurhynchium striatulum $^{1-5}(57)$, Radula complanata ${ }^{1-3}(57)$, Tortella tortuosa $a^{1-3}(52)$, Fissidens dubius ${ }^{1-4}(48)$, Porella platyphylla $^{1-3}(45)$, Neckera complanata ${ }^{1-4}(39)$, Pseudoleskeela catenulata ${ }^{1-4}(39)$, Bryum sp. ${ }^{1-3}(35)$, Homalothecium sericeum ${ }^{1-4}(35)$, Anomodon viticulosus ${ }^{1-5}(30)$, Cololejeunea calcarea ${ }^{1-4}(30)$, Pedinophyllum interruptum ${ }^{3}(30)$, Mnium thomsonii ${ }^{2-3}(30)$ etc. In cluster »B«, Mycelis muralis, Plagiochila porelloides ${ }^{1-3}(43)$, Mnium thomsonii, Quercus ilex $^{1-2}(13)$, Galeobdolon flavidum ${ }^{+3}(26)$ occur exclusively, while Cystopteris fragilis, Arabis alpina ${ }^{1-3}(52)$, Coronilla emerus subsp. emeroides $^{2-3}(19)$, Asparagus acutifolius ${ }^{1-2}$ (19), Hedera helix ${ }^{1-3}(13)$ occur almost exclusively. Here, three floristically well defined sub-clusters are recognized: (a) SaCM (On-line Supplement Tab. 4, rel. 7-31), representing floristic assemblages characterized by the presence and high coverage of Homalothecium sericeum $^{1-5}(84)$, Sesleria autumnalis ${ }^{1-5}(68)$ and Neckera besseri ${ }^{1-6}(52)$, Cyclamen purpurascens $^{+-3}(72)$, Galeobdolon flavidum ${ }^{+-3}(32)$ and Mycelis muralis ${ }^{+-3}(48)$; (b) SaCS (On-line Supplement Tab. 4, rel. 1-6), a group of floristically quite distinct stands with high frequency, coverage and (almost) exclusive occurrence of Coronilla emerus subsp. emeroides $^{2-3}(100)$, Asparagus acutifolius ${ }^{1-2}(100)$, Quercus ilex $x^{1-2}(66)$, Hedera helix $x^{1-3}(66)$, Lep- 
todon smithii ${ }^{3-6}(66)$ and Salvia officinalis ${ }^{1-2}(50)$; (c) CfC, stands characterized by exclusiveness, highest frequency and coverage of Mycelis muralis ${ }^{+-3}(87)$, Cystopteris fragilis ${ }^{2-4}(83)$, Geranium robertianum $^{1-3}(57)$, Arabis alpina ${ }^{1-3}(52)$, Plagiochila porelloides ${ }^{1-3}(43)$ and Mnium thomsonii ${ }^{2-3}$ (30; On-line Supplement Tab. 3).

Floristically, the cluster CfC which is the most different from cluster $\mathrm{SjC}(80.44 \%)$; the taxa that contribute most to dissimilarity are Sesleria juncifolia, Asplenium trichomanes, Cystopteris fragilis, Cymbalaria muralis, Mycelis muralis, Athamanta turbith, Globularia cordifolia, Asplenium ruta-muraria, Silene saxifraga subsp. hayekiana and Arabis alpina among the vascular plants, while among the bryophytes there are Necera crispa, Ctenidium molluscum, Homalothecium philippeanum, H. sericeum, Radula complanata, Tortella tortuosa and Schistidium sp. (Tab. 2). Cluster CfC differs significantly less from cluster SaC (65.92\%) and the taxa that contribute most to dissimilarity are Neckera crispa, Ctenidium molluscum, Anomodon viticulosus and many other bryophytes, while among the vascular plants the most important differential taxa are Cystopteris fragilis, Cymbalaria muralis, Sesleria autumnalis, Mycelis muralis, Asplenium trichomanes, A. ruta-muraria, Arabis alpina and Cyclamen purpurascens. The average dissimilarity between clusters $\mathrm{SjC}$ and $\mathrm{SaC}$ is $78.63 \%$, and the most important differential taxa are Sesleria juncifolia, S. autumnalis, Asplenium trichomanes, A. ruta-muraria, Globularia cordifolia etc. among vascular plants, and Neckera crispa, N. besseri, Anomodon viticulosus, Plasteurhynchium striatulum, Ctenidium molluscum etc. among bryophytes.

Specifically, groups of assemblages within the cluster SjC (SjCS, SjCGM, SjCGS and SjCC (Fig. 1) appear to be floristically most similar with overall average dissimilarities ranging between 55.61 (between SjCGM and SjCGS) and 72.82\% (between SjCS and SjCGS; On-line Supplement Tab. 1). Average dissimilarities between the cluster CfC and all the other groups of assemblages are in general high (72.26-84.52\%), while the most distinct group of assemblages is represented by the group SaCS with the highest recorded dissimilarities (86.5\% to SjCGM, 86.38\% to SjCGS and $80.37 \%$ to $\mathrm{SjCC}$ ). SaCS shows the lowest dissimilarity to $\mathrm{SaCM}(70.56 \%)$.

\section{Ecology and vegetation typology of stands}

Cluster topology (Fig. 1) reflects the ecology of chasmophytic assemblages well (Fig. $2)$. Cluster $» \mathrm{~A} «(\mathrm{SjC})$ includes stands of sunny and exposed rocky outcrops and cliffs, while cluster $\gg \mathrm{B}$ « represents stands fully- $(\mathrm{CfC})$ to semi-shaded $(\mathrm{SaC})$ by the tree canopy (Fig. 2F). Unconstrained ordination analysis (Fig. 2A) explains $25.3 \%$ of variance along the first axis, where assemblages preferring sunny and exposed sites $(\mathrm{SjC})$ are located on the left, while those occupying shaded and moist rock crevices $(\mathrm{SaC}, \mathrm{CfC})$ are on the lower right side of the diagram. The ecology of chasmophytic assemblages is even better reflected in results of constrained ordination analyses (Figs. 2B-F). CCA analysis of all assemblages (Fig. 2B) yields coverage $(\mathrm{F}=5.56)$ and number of bryophyte taxa (2.42), elevation (5.47) and number of vascular plants (1.85) as statistically significant explanatory variables $(\mathrm{p}<$ $0.002)$. In coverage and number of respective bryophyte taxa assemblages of the cluster $\mathrm{CfC}$, and partly of $\mathrm{SaC}$ dominate. These stands prefer sciophytic, moist, nutrient-rich and higher-elevated sites. In contrast, assemblages of cluster $\mathrm{SjC}$, depauperate in number and coverage of bryophyte taxa, prefer open sites along the broad elevational range. Assemblages of the cluster $\mathrm{SaC}$ seem to be ecologically somewhat intermediate, preferring semi- 
Surina B., MARTINČIČ A.

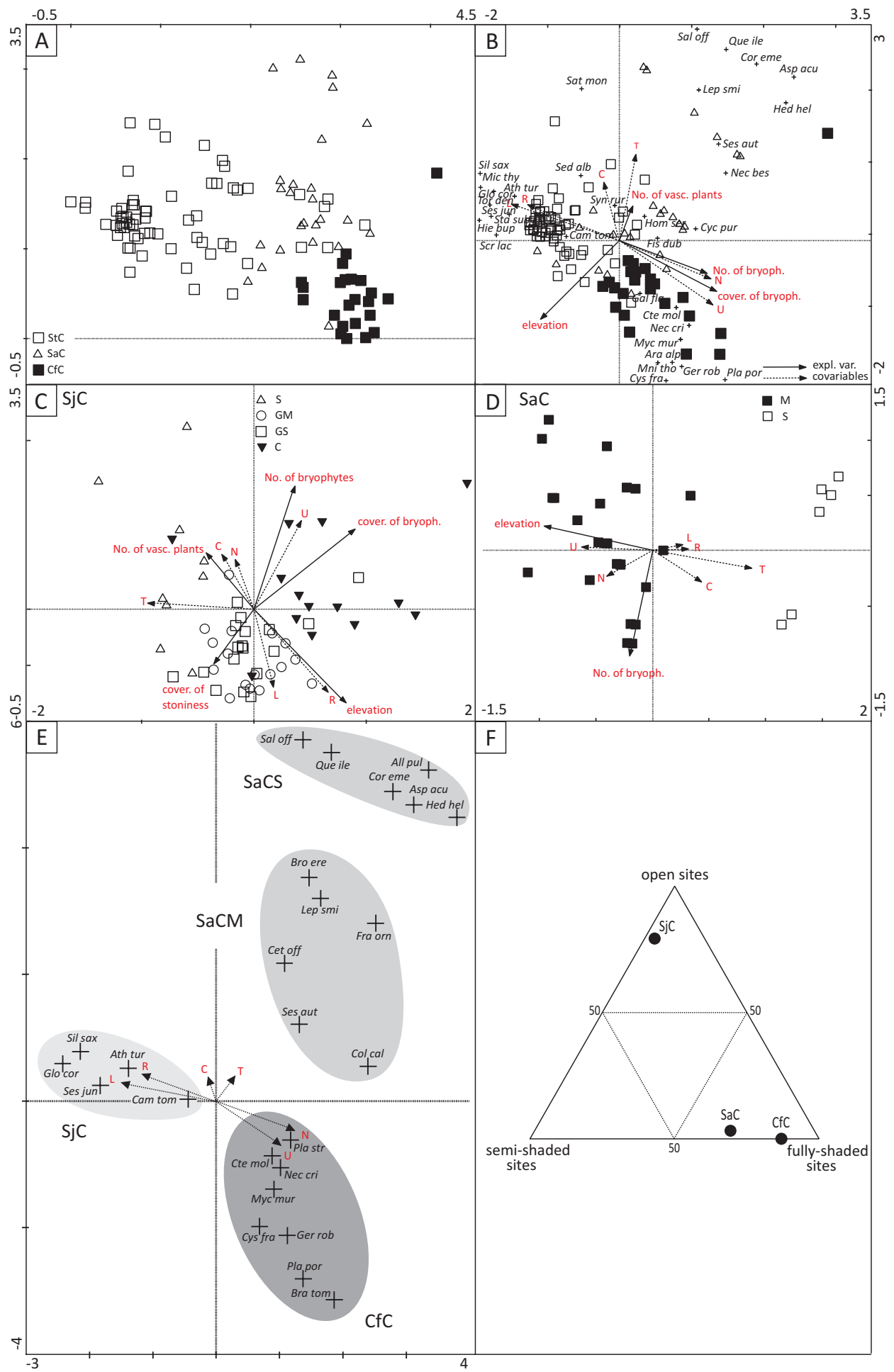


or fully shaded sites most commonly within thermophytic beech forests of the association Seslerio autumnalis-Fagetum. Elevation is negatively correlated with the number of vascular plant taxa, where a group of $\mathrm{SaC}$ assemblages from lower elevated sites is well differentiated from all other stands in floristic richness, distinct composition as well as most thermophytic site conditions.

Using an inclusion rule in order to define a subset of species that fit the quality criterion of representing the percentage of variability in species values explained by the explanatory variables, the following groups of species are identified (Fig. 2E): Sesleria juncifolia, Athamanta cretensis, Silene saxifraga subsp. hayekiana, Globularia cordifolia and Campanula tommasiniana for the group SjC; Cystopteris fragilis, Mycelis muralis, Neckera crispa, Ctenidium molluscum, Geranium robertianum, Plagiochila porelloides, Brachythecum tommasinii and Plasteurhynchium striatulum for the group CfC; Sesleria autumnalis, Fraxinus ornus, Ceterach officinarum, Leptodon smithii, Bromus erectus and Cololejeunea calcarea for the group SaCM, and Quercus ilex, Salvia officinalis, Coronilla emerus subsp. emeroides, Allium pulchellum subsp. carinatum, Asparagus acutifolius and Hedera helix for the group SaCS.

The results of the non-parametric test for equal medians of environmental values of chasmophytic assemblages (Tab. 3) show significant differences $(p<0.05)$ in both site parameters and Pignatti's indicator values (Tab. 3). Generally, moisture $(\mathrm{U}, \mathrm{H}=87.94)$ and light conditions (L, 84.91) show the highest probability of non-equal medians of environmental values in the studied assemblages, followed by soil reaction ( $R, 80.78)$, coverage of bryophytes (76.61), nutrients $(\mathrm{N}, 67.85)$ and elevation (50.82). Post-hoc pairwise comparisons suggest that stands from the cluster $» A «(S j C)$ significantly differ from all the other groups in light conditions, moisture, soil reaction, amount of nutrients and coverage of bryophytes. On the other hand, group CfC differs significantly from all the other groups in moisture and soil reaction, while the group $\mathrm{SaC}$ represents relatively mesophytic assemblages. According to initial cluster, and subsequent unconstrained and constrained ordination analyses, further easily recognized groups of assemblages are recognized based on specifics in site ecology and floristic assembly. Within the group $\mathrm{SjC}$, a subset of stands $\mathrm{SjCS}$, characterized by the presence and high coverage of Sedum album, Satureja montana

Fig. 2. Unconstrained and constrained analyses of chasmophytic assemblages with Campanula tommasiniana on Mt. Učka (NW Adriatic) according to site parameters and Pignatti's indicator values. A - DCA diagram, length of gradient 4.071, eigenvalues 0.533, 0.340, 0.212, 0.159; cumulative percentage variance of species data: $6.4,10.6,13.1,15.0 ; \mathbf{B}$ - CCA diagram according to site parameters and Pignatti indicator values; eigenvalues: 0.429, 0.362, 0.151, 0.122 ; cumulative percentage variance of species data: 5.2, 9.6, 11.4, 12.8; $\mathbf{C}$-CCA diagram of stands of the assemblage group $\mathrm{SjC}$; eigenvalues: 0.284, 0.248, 0.164, 0.140; cumulative percentage variance of species data: 5.4, 10.1, 13.3, 15.9; $\mathbf{D}$ - CCA diagram of stands of the assemblage group SaC; eigenvalues: 0.386, 0.231, 0.297, 0.257; cumulative percentage variance of species data: $8.8,14.1,20.9,26.8 ; \mathbf{E}-$ CCA diagram of species-environmental data using inclusion rule (25\%) option; $\mathbf{F}$ - ternary plot for the three types of assemblages according to light condition of sites. Full lines - explanatory variables: site parameters (elevation, number of vascular plants, number of bryophytes, coverage of bryophytes, coverage of stoniness); dashed lines - co-variables: passively projected Pignatti indicator values $(\mathrm{L}-$ light conditions, $\mathrm{T}$ - temperature, $\mathrm{R}$ - soil reaction, $\mathrm{C}$ - continentality, $\mathrm{U}$ - moisture, $\mathrm{N}$ - nutrients). Syntaxonomy is explained in the text following figure 3 . 
Surina B., MARTinčIČ A.

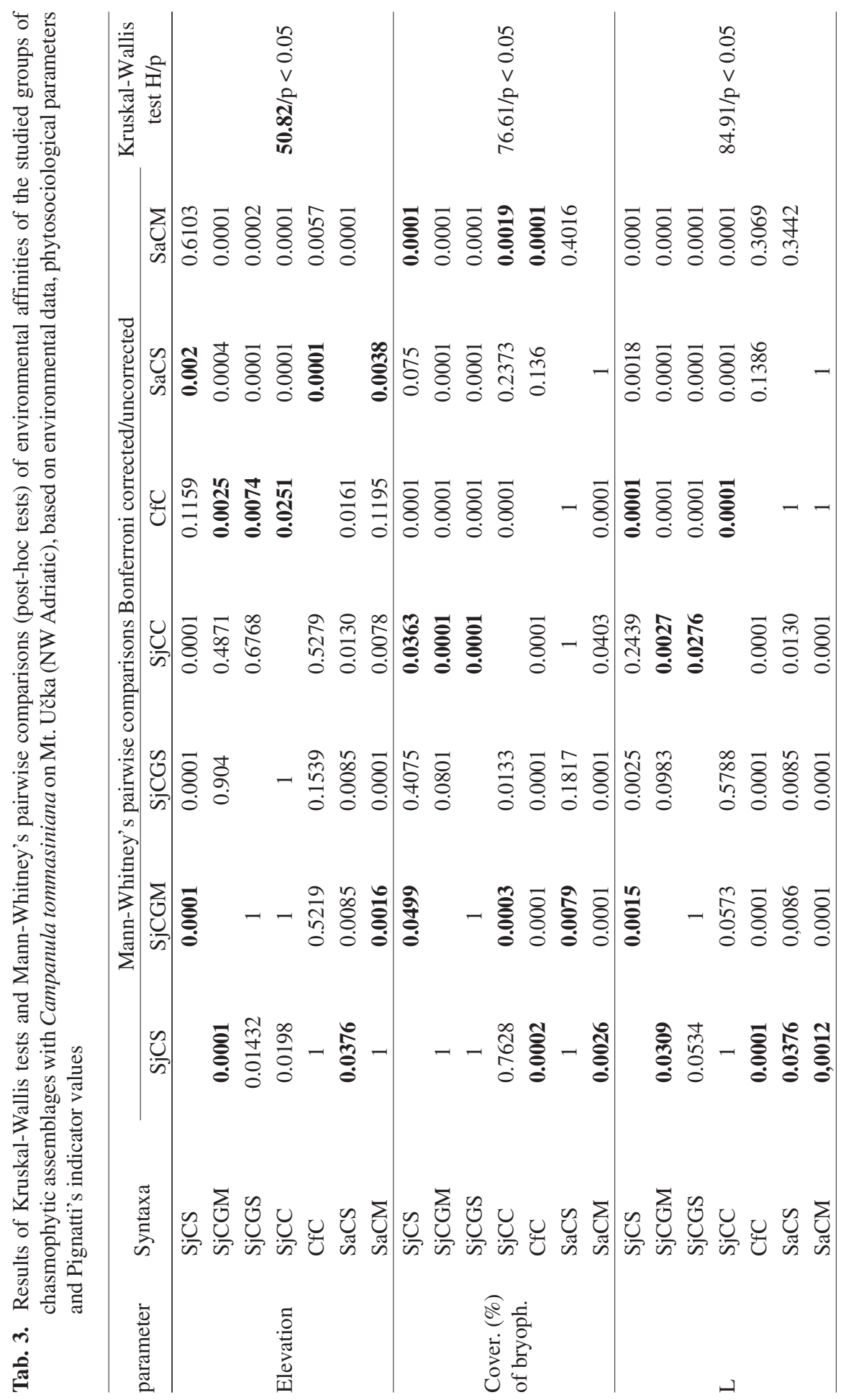




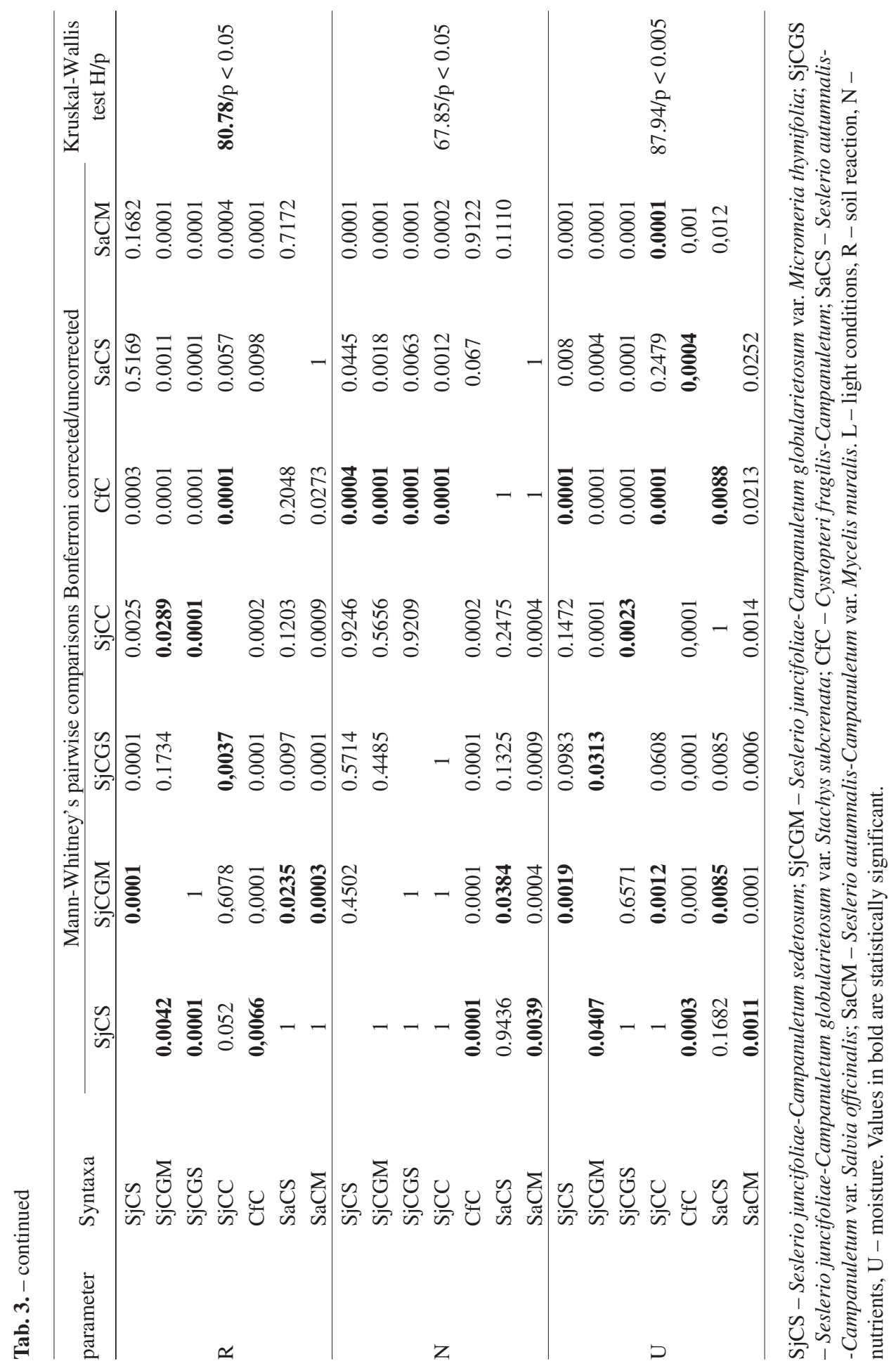



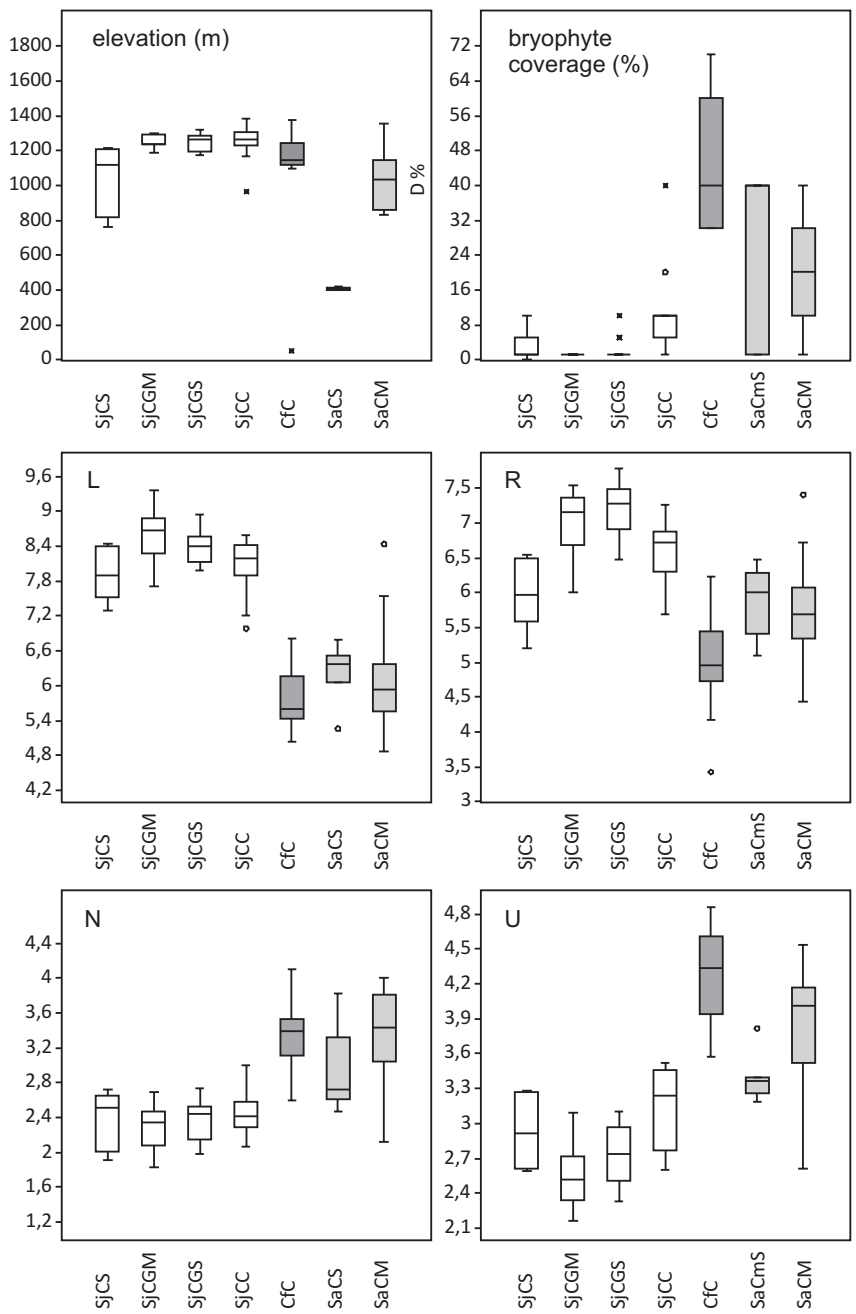

Fig. 3. Box plots of environmental parameters (elevation, coverage of bryophytes) and Pignatti's indicator values ( $\mathrm{L}$ - light conditions, $\mathrm{R}$-soil reaction, $\mathrm{N}$ - nutrients, $\mathrm{U}$ - moisture) of floristically distinct chasmophytic assemblages with Campanula tommasiniana on Mt. Učka (NW Adriatic).Syntaxonomy (x-axis) is explained in the text below.

subsp. variegata and Syntrichia ruralis var. ruralis, prefers warmer, open to semi shaded and significantly lower-elevated sites and relatively lower soil $\mathrm{pH}$ reaction in an otherwise broad elevational range (Tab. 3, Figs. 2C, 3). SjCC subset is characterized by a significantly higher number and coverage of bryophytes, particularly Ctenidium molluscum, Neckera crispa and Fissidens dubius and prefers moister rock crevices in higher elevated sites. The two subsets, SjCGM and SjCGS, respectively, although differing well floristically, show the only significant differentiation in site moisture where the subset SjCGM, characterized by the presence and high coverage of Globularia cordifolia, Hieracium bupleuroides, Micromeria thymifolia and Scrophularia laciniata, prefers slightly dryer and more exposed sites. Among the explanatory variables, four statistically significant parameters are identified by 
CCA analysis (Fig. 2B) : coverage ( $\mathrm{F}=2.69)$ and number (1.80) of bryophytes, elevation (2.70) and number of vascular plants (2.00). Two subsets of assemblages is are recognized within the group $\mathrm{SaC}$ (Fig. 2D, Tabs.1, 3): SaCS, characterized by the exclusive occurrence, high frequency and coverage of Coronilla emerus subsp. emeroides, Asparagus acutifolius, Quercus ilex, Hedera helix and Salvia officinalis, developed on significantly drier and lower elevated sites; and SaCM, where the differential group of taxa is represented by Cyclamen purpurascens, Galeobdolon flavidum and Mycelis muralis, species otherwise frequent in the beech forest understorey. Here, CCA analysis (Fig. 2D) gives only elevation $(\mathrm{F}=2.64)$ and number of bryophytes (1.74) as statistically significant explanatory variables.

Hemicryptophytes achieve the highest coverage in group $\mathrm{StS}$ and the lowest in groups SjCC and CfC (Tab. 1). Chamaephytes are most abundant in groups $\mathrm{SjC}$, while they are absent in group CfC. In number and coverage of phanerophytes, the group SaCS departs significantly from all the other groups. Accodingly, no therophytes were surveyed in this group.

\section{Syntaxonomy, nomenclature and typification of the syntaxa}

We propose three new associations, seven new lower ranked syntaxa and the following classification scheme:

Asplenietea trichomanis Br.-Bl. et Maire 1934 corr. Oberd. 1977

Potentilletalia caulescentis Br.-B1. in Br.-B1. et Jenny 1926

Potentillion caulescentis Br.-Bl. in Br.-Bl. et Jenny 1926

Physoplexido-Potentillenion caulescentis Theurillat in Theurillat et al. 1995

Seslerio juncifoliae-Campanuletum tommasinianae ass. nov. (SjC) sedetosum albae subass. nov. (SjCS)

globularietosum cordifoliae subass. nova (SjCG)

var. Micromeria thymifolia var. nova (SjCGM)

var. Stachys subcrenata var. nova (SjCGS)

ctenidietosum mollusci subass. nova (SjCC)

Moehringion muscosae Horvat et Horvatić 1962

Seslerio autumnalis-Campanuletum tommasinianae ass. nova (SaC)

(=Campanuletum tommasinanae-justinianae Horvatić 1960 nom. nud.)

var. Salvia officinalis (SaCS)

var. Mycelis muralis (SaCM)

Cystopteri fragilis-Campanuletum tommasinianae ass. nova (CfC)

Characteristic group of taxa for the association Seslerio juncifoliae-Campanuletum are Campanula tommasiniana, Sesleria juncifolia, Athamanta turbith and Silene saxifraga subsp. hayekiana (Tab. 4, On-line Supplement Tab. 2); differential group of taxa for the subassociation sedetosum are Sedum album, Satureja montana subsp. variegata and Syntrichia ruralis var. ruralis; differential group of taxa for the subassociation globularietosum are Globularia cordifolia and Hieracium bupleuroides (Micromeria thymifolia, Scrophularia laciniata and Stachys subcrenata, Tortella densa for the variants Micromeria thymifolia and Stachys subcrenata, respectively); differential group of taxa for the subassociation ctenidietosum mollusci are Ctenidium molluscum, Neckera crispa and Fissidens dubius. A characteristic group of taxa for the association Seslerio autumnalis-Campanuletum are 
Surina B., MARTinčIČ A.

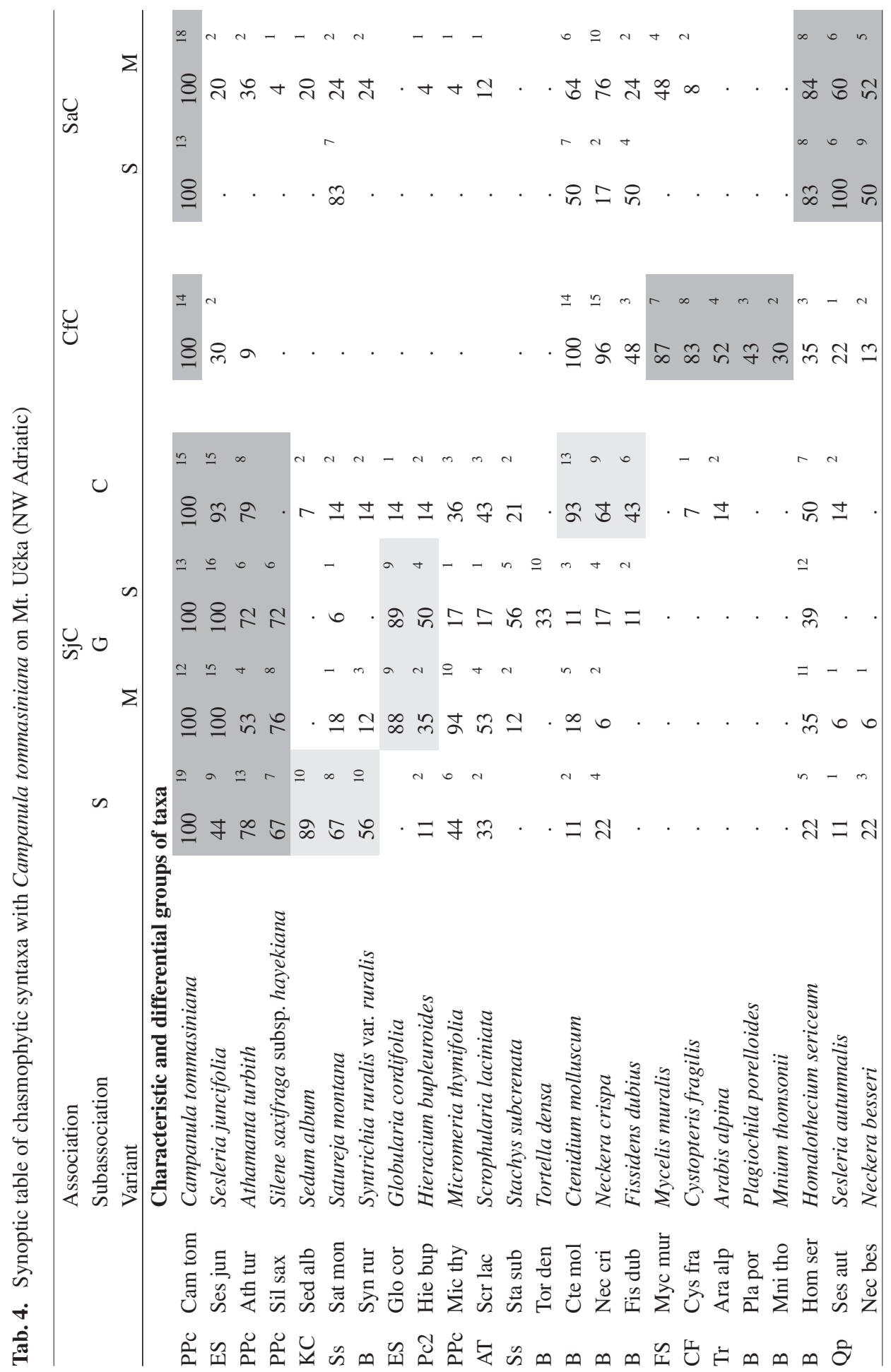




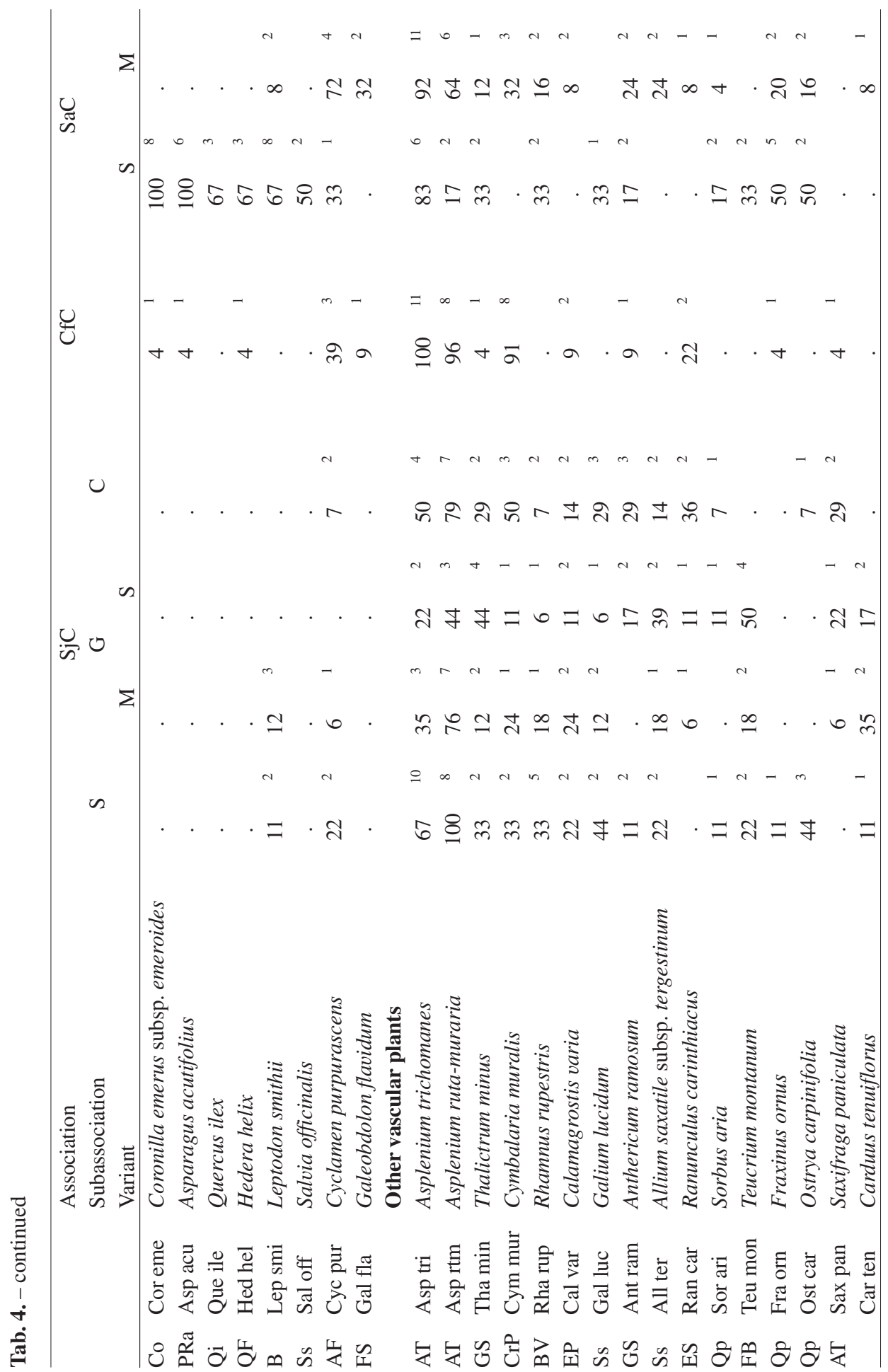


SURINA B., MARTINČIČ A.

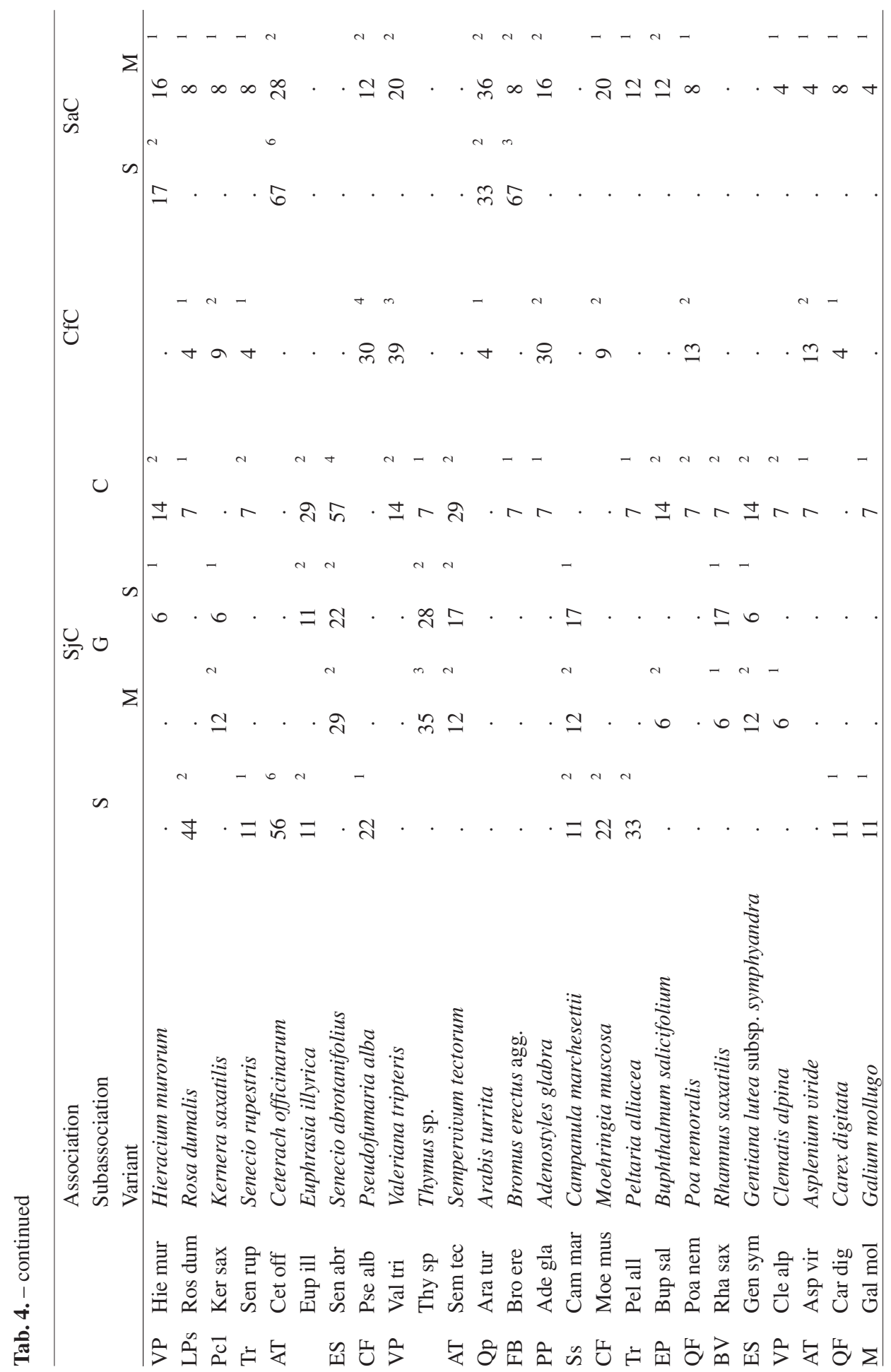




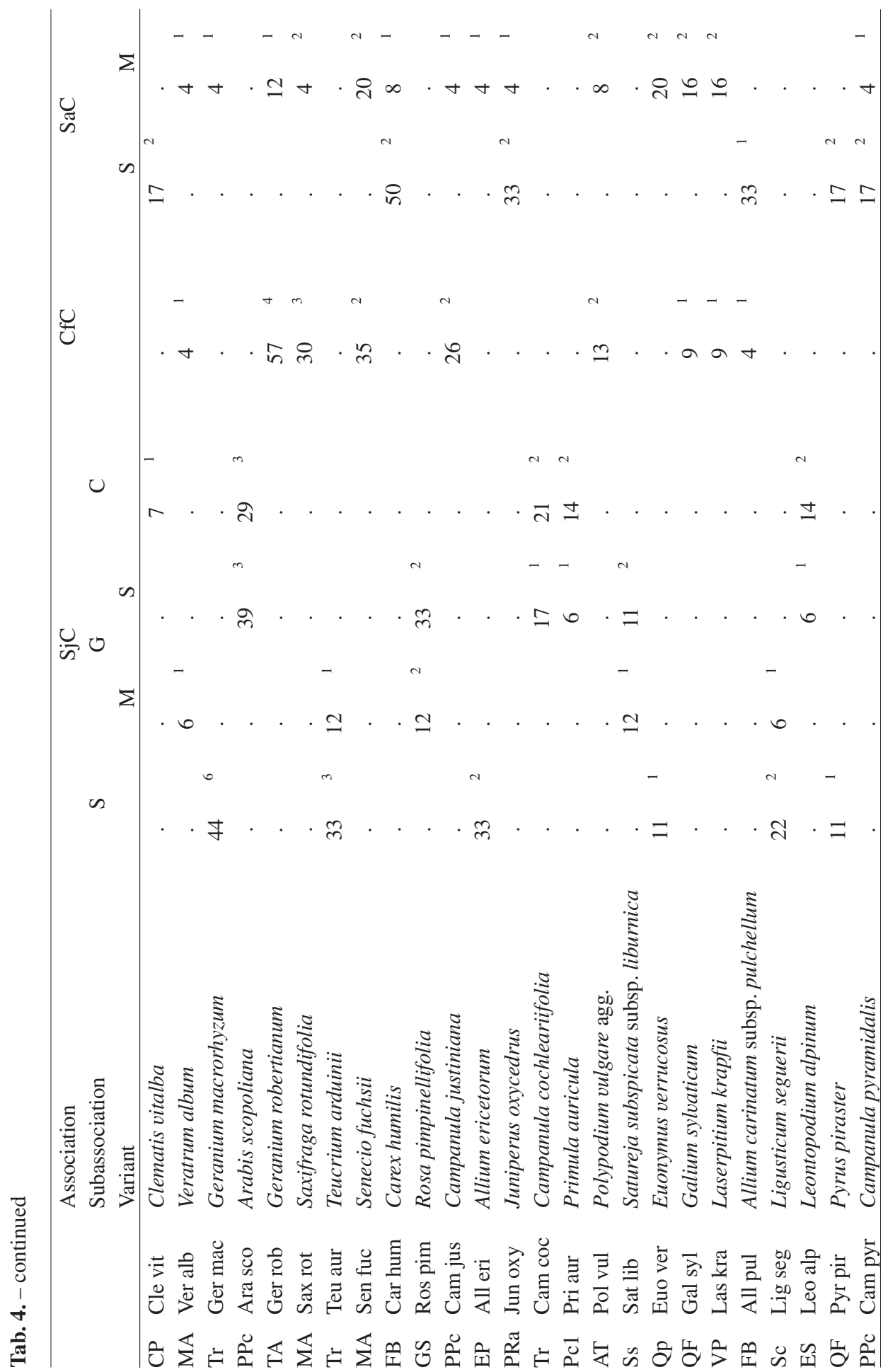


SURINA B., MARTINČIČ A.

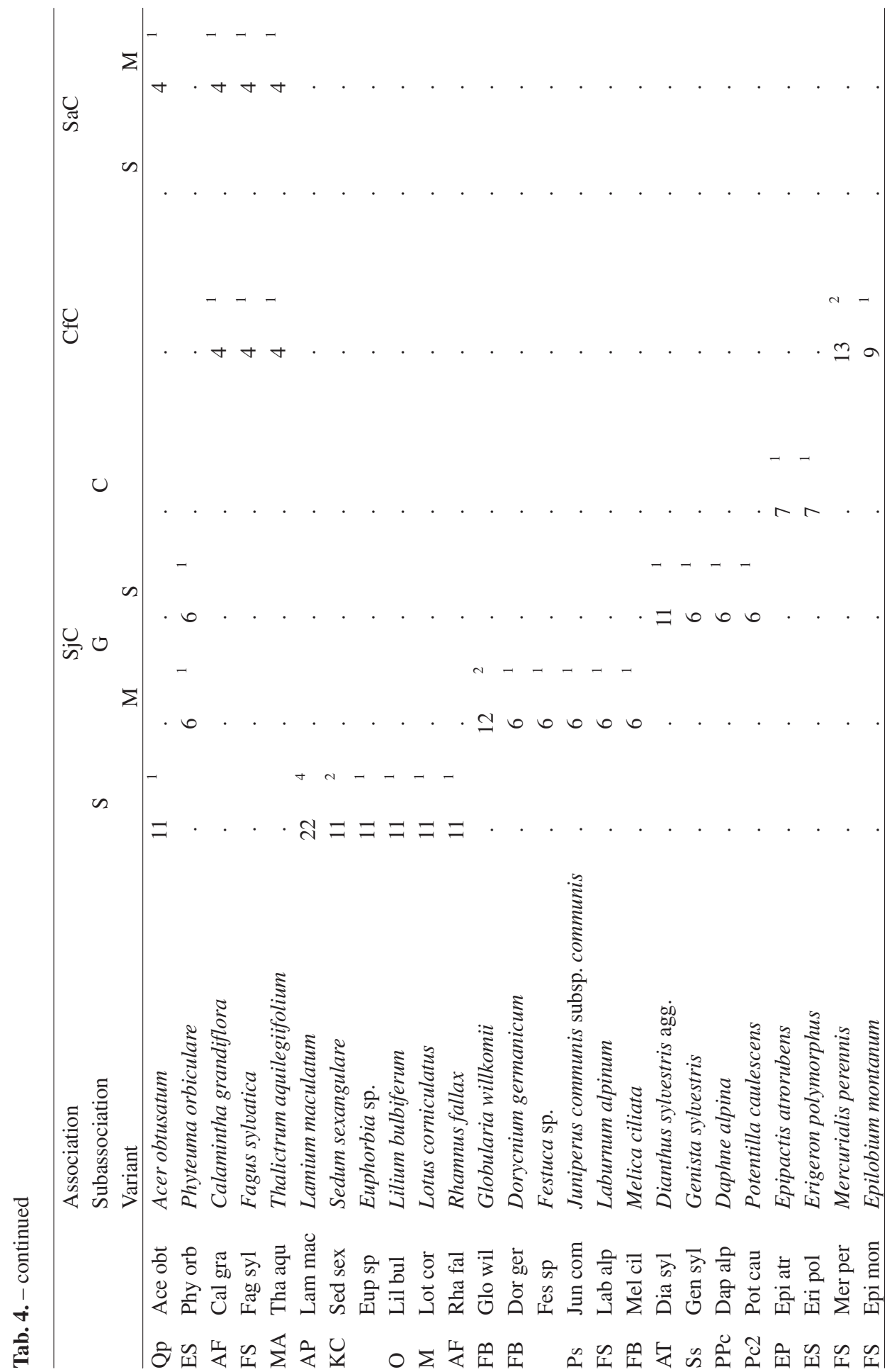




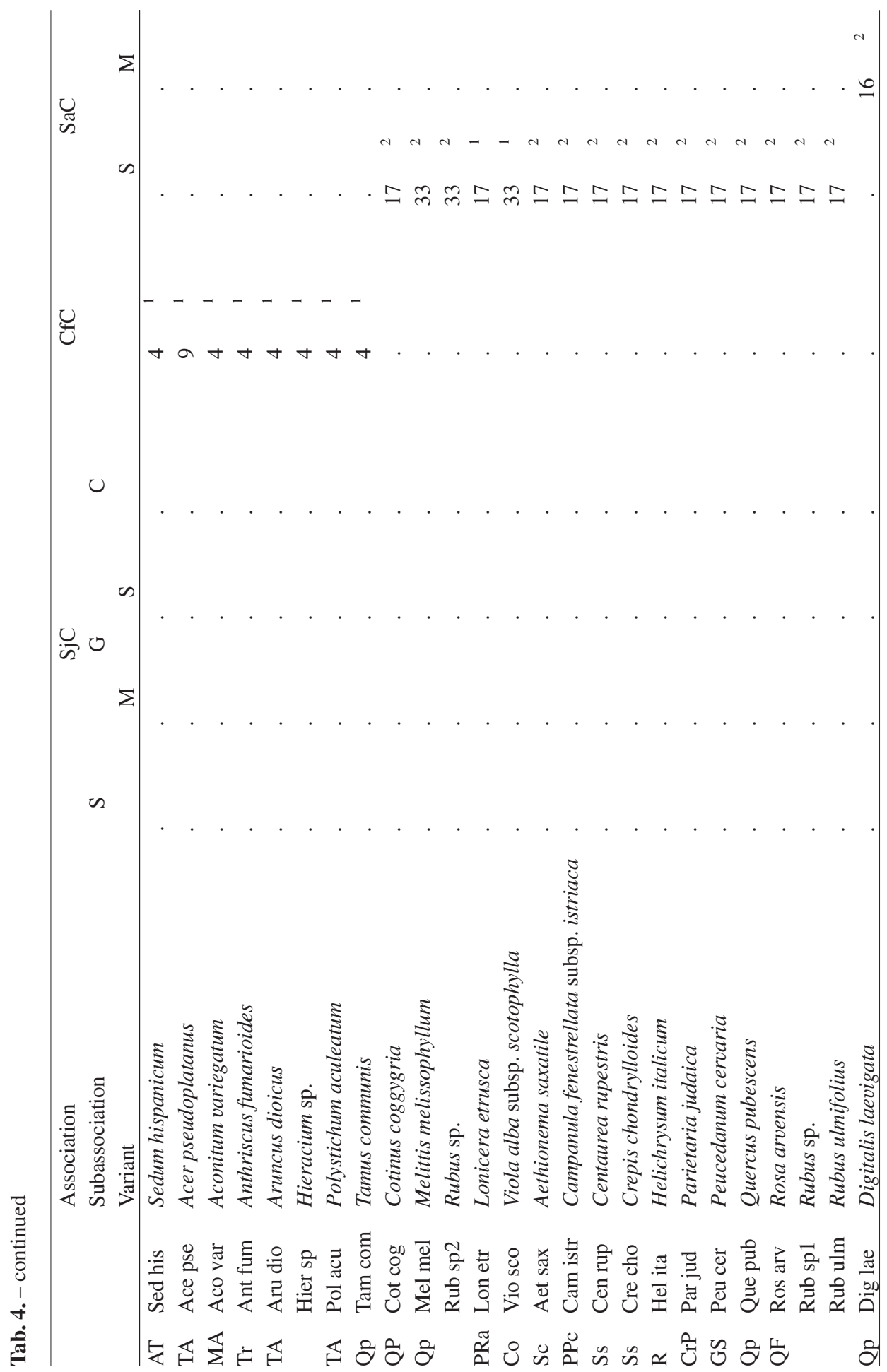


SURINA B., MARTINČIČ A.

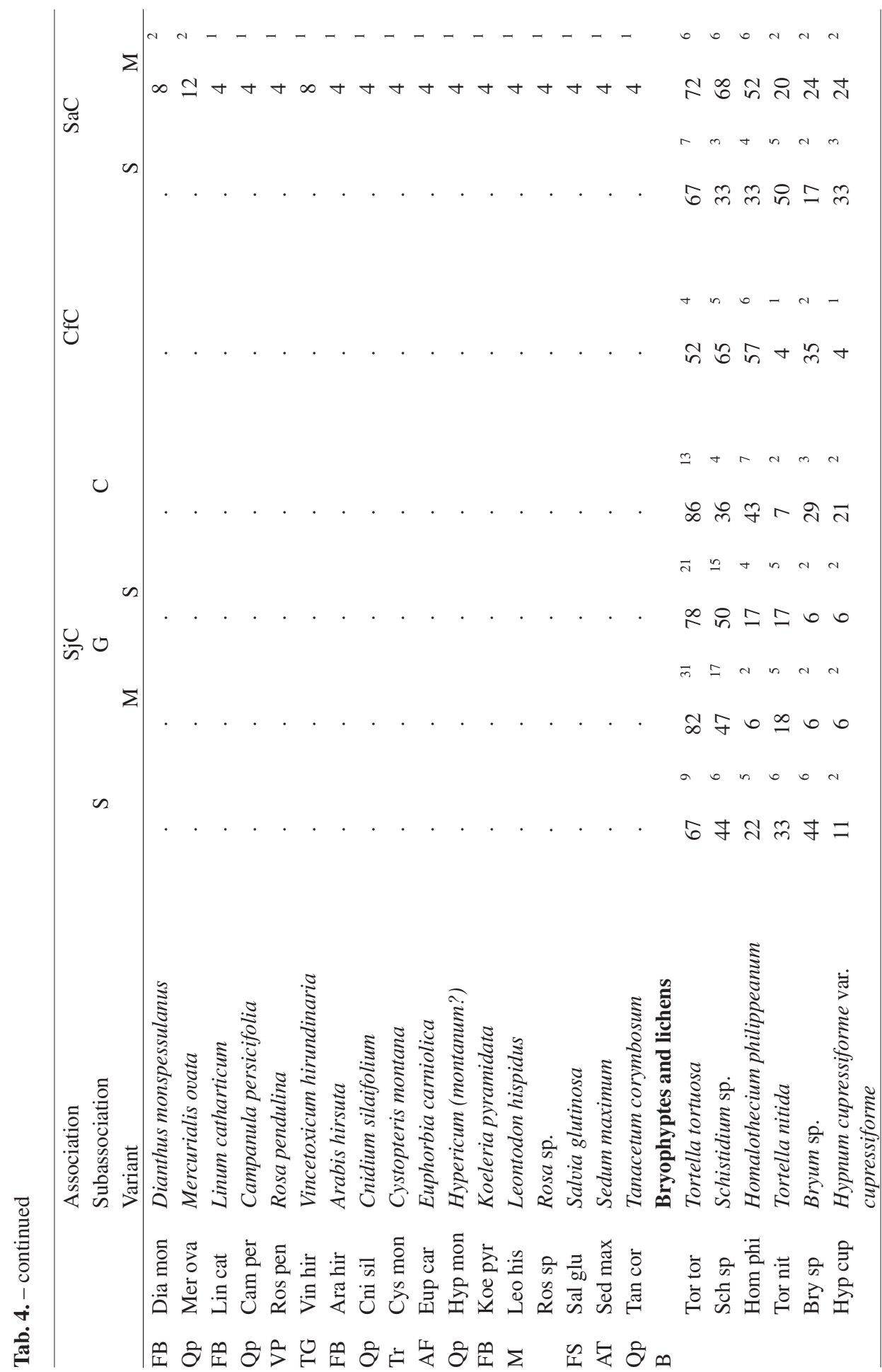




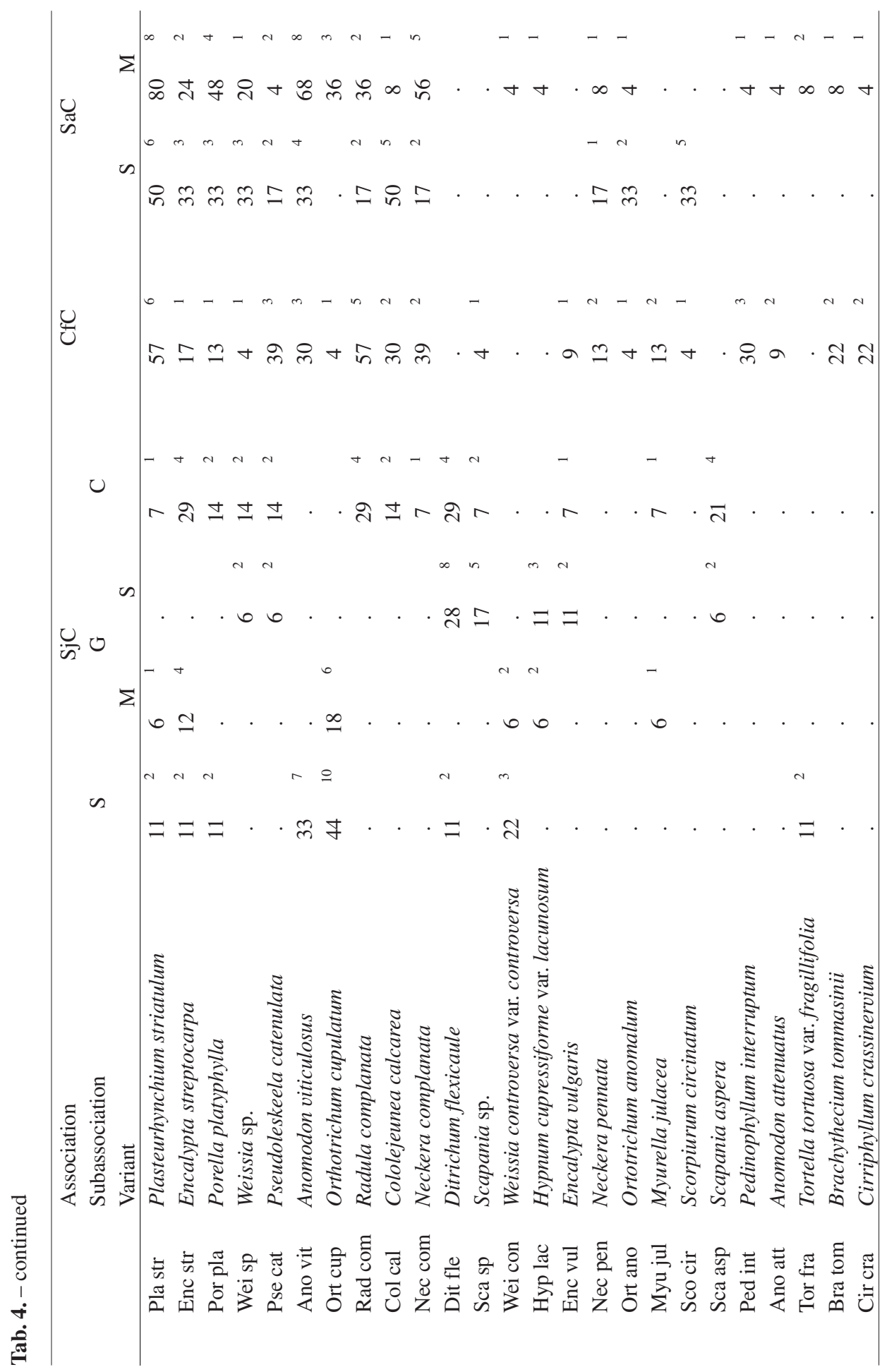


SURINA B., MARTINČIČ A.

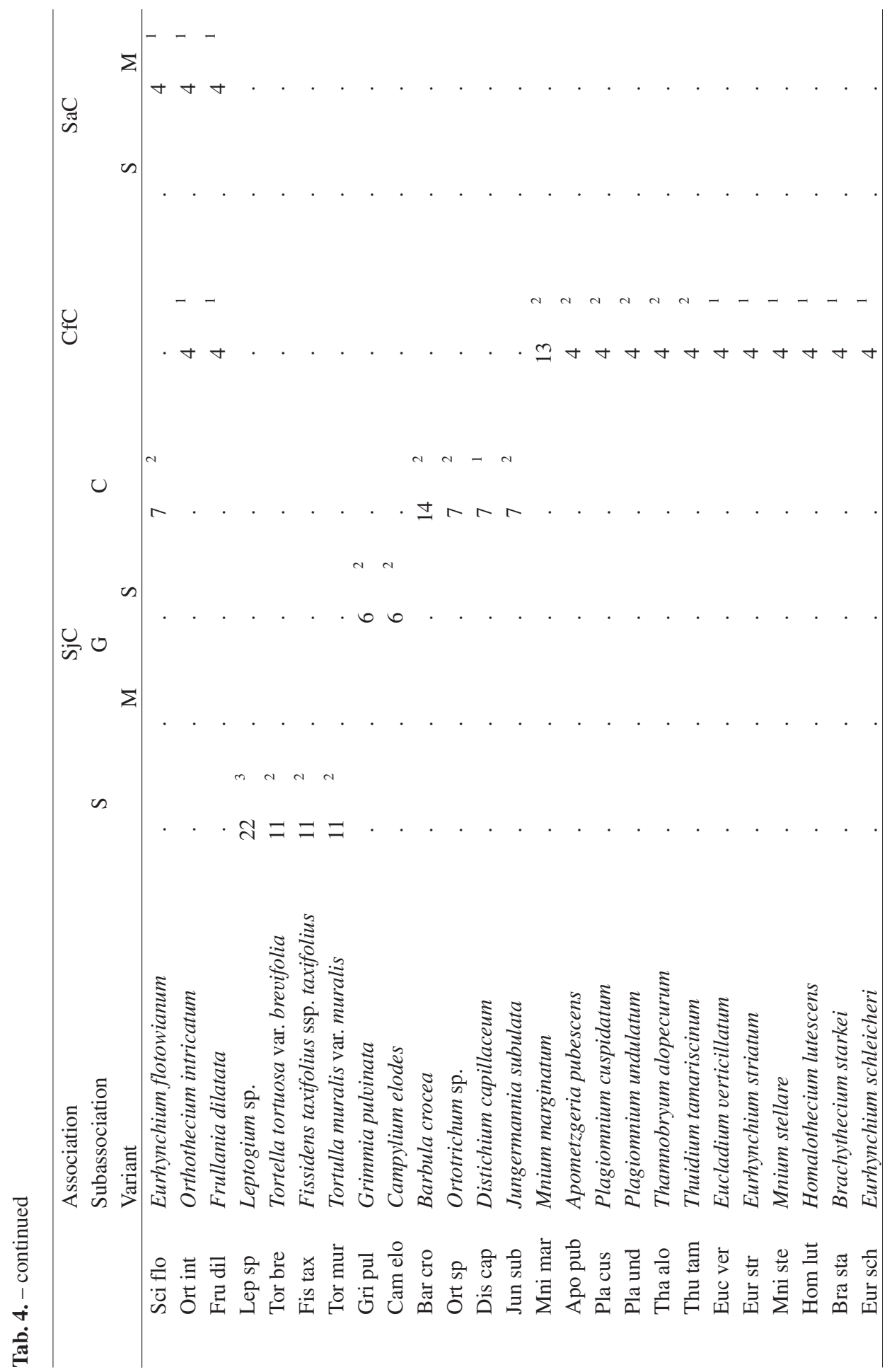




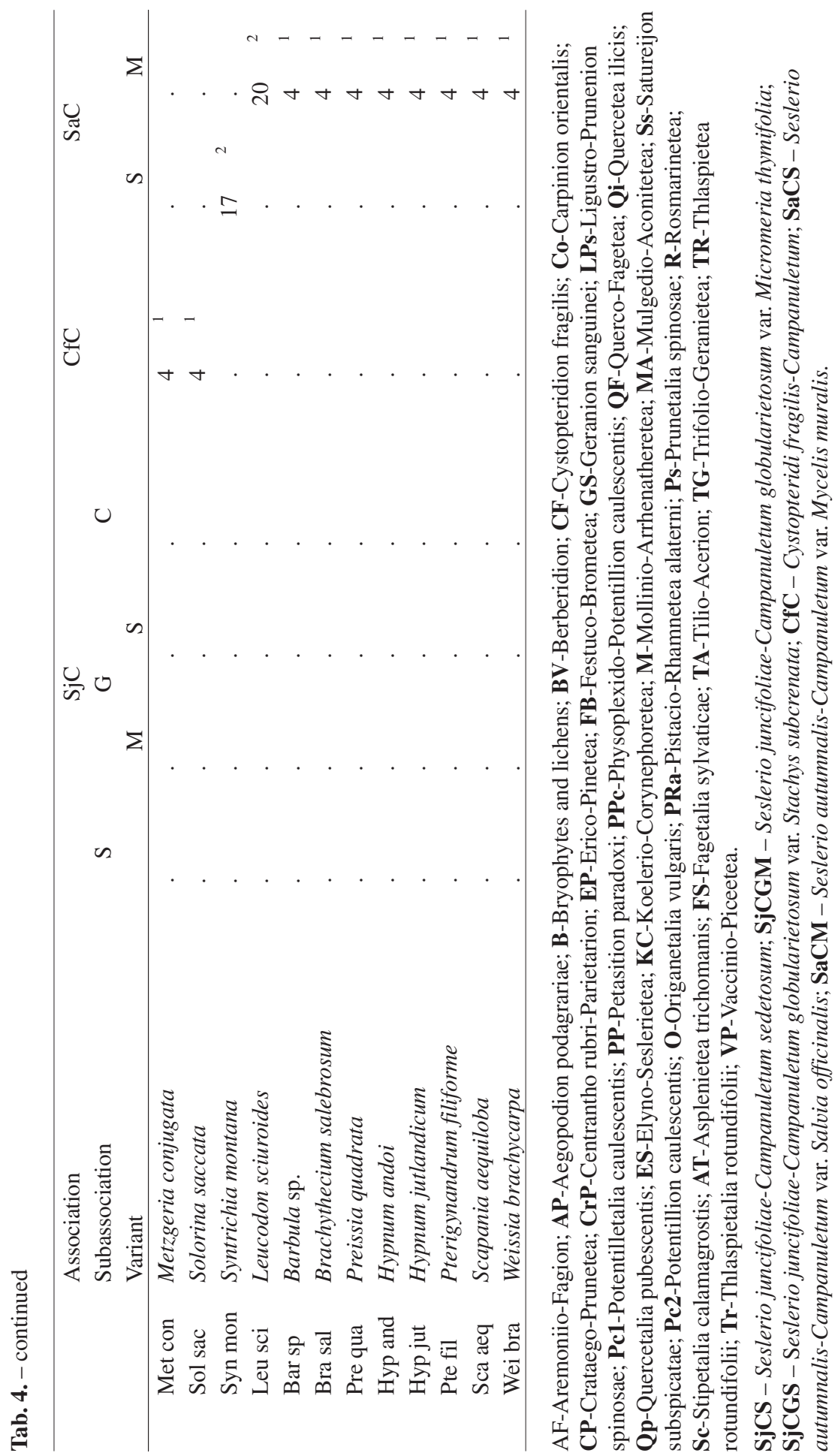


Campanula tommasiniana, Sesleria autumnalis, Homalothecium sericetum and Neckera besseri (Tab. 4, On-line Supplement Tab. 4); a differential group of taxa for the variant Salvia officinalis are Coronilla emerus subsp. emeroides, Quercus ilex, Asparagus acutifolius, Hedera helix, Leptodon smithii and Salvia officinalis, and for the variant Mycelis muralis: Cyclamen puprurascens, Mycelis muralis and Galeobdolon flavidum. A characteristic group of taxa for the association Cystopteri fragilis-Campanuletum are Campanula tommasiniana, Mycelis muralis, Cystopteris fragilis, Geranium robertianum, Arabis alpina, Plagiochila porelloides and Mnium thomsonii (Tab. 4, On-line Supplement Tab. 3). Characteristic and differential taxa for the newly described syntaxa are indicated in Fig. 2 B.

Seslerio juncifoliae-Campanuletum tommasinianae ass. nov. globularietosum cordifoliae subass. nova var. Micromeria thymifolia var. nova. Nomenclatorial type for the association, subassociation and variant (holotypus): Croatia, NW Adriatic, Liburnian karst, Mt. Učka, eastern slope; elev. $1287 \mathrm{~m}$, exp. ESE, incl. $90^{\circ}$; relevé area: $8 \mathrm{~m}^{2}$, coverage of the relevé area: vascular plants-10\%, bryophytes-1\%; calcareous rocky outcrop not shaded by the tree canopy (rel. no 22 in On-line Supplement Tab. 2): Sesleria juncifolia 3, Campanula tommasiniana 2, Globularia cordifolia 2, Homalothecium sericeum 2, Micromeria thymifolia 2, Saxifraga paniculata 2, Scrophularia laciniata 2, Silene saxifraga subsp. hayekiana 2, Thymus sp. 2, Tortella nitida 2, Athamanta turbith 1, Carduus tenuiflorus 1, Hieracium bupleuroides 1, Syntrichia ruralis var. ruralis 1.

Seslerio juncifoliae-Campanuletum tommasinianae globularietosum cordifoliae var. Stachys subcrenata var. nova. Nomenclatorial type for the variant (holotypus): Croatia, NW Adriatic, Liburnian karst, Mt. Učka, western slope; elev. 1278 m, exp. SSW, incl. 90; relevé area: $10 \mathrm{~m}^{2}$, coverage of the relevé area: vascular plants-20\%, bryophytes-1\%; calcareous rocky outcrop not shaded by the tree canopy (rel. no 38 in On-line Supplement Tab. 2): Campanula tommasiniana 4, Sesleria juncifolia 4, Asplenium ruta-muraria 3, Athamanta turbith 3, Ditrichium flexicaule 3, Globularia cordifolia 3, Tortella densa 3, T. tortuosa 3, Schistidium sp. 3, Senecio abrotanifolius 2, Silene saxifraga subsp. hayekiana 2, Stachys subcrenata 2, Teucrium montanum 2, Carduus tenuiflorus 1, Sempervivum tectorum 1, Primula auricula 1.

Seslerio juncifoliae-Campanuletum tommasinianae sedetosum albae subass. nova. Nomenclatorial type for the subassociation (holotypus): Croatia, NW Adriatic, Liburnian karst, Mt. Učka, eastern slope; elev. $760 \mathrm{~m}$, exp. NE, incl. 85'; relevé area: $20 \mathrm{~m}^{2}$, coverage of the relevé area: vascular plants-20\%, bryophytes-10\%; calcareous rock not shaded by the tree canopy (rel. no. 3 in On-line Supplement Tab. 2): Campanula tommasiniana 4, Sesleria juncifolia 4, Allium saxatile subsp. tergestinum 3, Anomodon viticulosus 3, Asplenium ruta-muraria 3, Athamanta turbith 3, Ceterach officinarum 3, Ctenidium molluscum 3, Ditrichium flexicaule 3, Homalothecium sericeum 3, Hypnum cupressiforme var. cupressiforme 3, Leptodon smithii 3, Neckera besseri 3, N. crispa 3, Orthotrichum cupulatum 3, Schistidium sp. 3, Silene saxifraga subsp. hayekiana 3, Syntrichia ruralis var. ruralis 3, Tortella tortuosa 3, Rhamnus rupestris 2, Sedum album 2, Allium ericetorum 1, Asplenium trichomanes 1, Satureja montana subsp. variegata 1.

Seslerio juncifoliae-Campanuletum tommasinianae ctenidietosum mollusci subass. nova. Nomenclatorial type for the subassociation (holotypus): Croatia, NW Adriatic, Liburnian karst, Mt. Učka, eastern slope; elev. 1235 m, exp. SE, incl. 85 ; relevé area: $10 \mathrm{~m}^{2}$, coverage of the relevé area: vascular plants- $40 \%$, bryophytes- $10 \%$; calcareous rock not shaded by the 
tree canopy (rel. no. 45 in On-line Supplement Tab. 2): Calamagrostis varia 4, Sesleria juncifolia 4, Asplenium ruta-muraria 3, A. trichomanes 3, Athamanta turbith 3, Campanula tommasiniana 3, Galium corrudifolium 3, Anthericum ramosum 2, Bryum sp. 2, Ctenidium molluscum 2, Cymbalaria muralis 2, Euphrasia illyrica 2, Fissidens dubius 2, Homalothecium sericeum 2, Micromeria thymifolia 2, Neckera crispa 2, Saxifraga paniculata 2, Schistidium sp. 2, Scrophularia laciniata 2, Sedum album 2, Senecio abrotanifolius 2, Syntrichia ruralis var. ruralis 2, Tortella tortuosa 2, Homalothecium philippeanum 1, Hypnum cupressiforme var. cupressiforme 1, Ranunculus carinthiacus 1 , Silene saxifraga subsp. hayekiana 1, Thalictrum minus 1, Gentiana lutea subsp. symphyandra +.

Seslerio autumnalis-Campanuletum tommasinianae var. Mycelis muralis ass. and var. nova. Nomenclatorial type for the association and the variant (holotypus): Croatia, NW Adriatic, Liburnian karst, Mt. Učka, western slope; elev. 1055 m, exp. E, incl. 85 ; relevé area: $16 \mathrm{~m}^{2}$, coverage of the relevé area: vascular plants-40\%, bryophytes-30\%; calcareous rock fully shaded by the tree canopy (rel. no. 28 in On-line Supplement Tab. 4): Anomodon viticulosus 5, Neckera crispa 5, Campaula tommasiniana 4, Pseudofumaria alba 4, Asplenium trichomanes 3, Ctenidium molluscum 3, Cyclamen purpurascens 3, Galeobdolon flavidum 3, Geranium robertianum 3, Homalothecium sericeum 3, Mercurialis ovata 3, Moehringia muscosa 3, Mycelis muralis 3, Neckera besseri 3, N. complanata 3, Plasteurhynchium striatulum 3, Porella platyphylla 3, Valeriana tripteris 3, Arabis turrita 2, Athamanta turbith 2, Brachythecium tommasinii 1, Galium sylvaticum 1, Hypnum cupressiforme var. cupressiforme 1, Laserpitium krapfii 1, Radula complanata 1, Senecio fuchsii 1, Sesleria autumnalis 1, S. juncifolia 1, Ceterach officinarum + , Peltaria alliacea + .

Seslerio autumnalis-Campanuletum tommasinianae var. Salvia officinalis var. nova. Nomenclatorial type for the variant (holotypus): Croatia, NW Adriatic, Liburnian karst, Mt. Učka, eastern slope; elev. 396 m, exp. SE, incl. 90; relevé area: $18 \mathrm{~m}^{2}$, coverage of the relevé area: vascular plants-30\%, bryophytes-1\%; calcareous rock semi shaded by the tree canopy (rel. no. 1 in On-line Supplement Tab. 4): Campanula tommasiniana 4, Coronilla emerus subsp. emeroides 3, Homalothecium sericeum 3, Leptodon smithii 3, Satureja montana subsp. variegata 3, Schistidium sp. 3, Teucrium montanum 3, Tortella nitida 3, Weissia sp. 3, Arabis turrita 2, Asparagus acutifolius 2, Asplenium trichomanes 2, Bromus erectus agg. 2, Ceterach officinarum 2, Juniperus oxycedrus 2, Ostrya carpinifolia 2, Rhamnus rupestris 2, Sesleria autumnalis 2, Galium corrudifolium 1, Hedera helix 1, Neckera besseri 1, Ortotrichum anomalum 1, Quercus ilex 1, Salvia officinalis 1, Thalictrum minus 1.

Cystopteri fragilis-Campanuletum tommasinianae ass. nova. Nomenclatorial type for the association (holotypus): Croatia, NW Adriatic, Liburnian karst, Mt. Učka, eastern slope; elev. $1297 \mathrm{~m}$, exp. NE, incl. $90^{\circ}$; relevé area: $12 \mathrm{~m}^{2}$, coverage of the relevé area: vascular plants-40\%, bryophytes-60\%; calcareous rock fully shaded by the tree canopy (rel. no. 3 in On-line Supplement Tab. 3): Neckera crispa 7, Pseudofumaria alba 7, Campanula tommasiniana 6, Ctenidium molluscum 6, Anomodon viticulosus 4, Brachythecium tommasinii 4, Homalothecium sericeum 4, Mnium marginatum 4, Plasteurhynchium striatulum 4, Saxifraga rotundifolia 4, Arabis alpina 3, Asplenium trichomanes 3, Bryum sp. 3, Cymbalaria muralis 3, Cystopteris fragilis 3, Geranium robertianum 3, Mnium thomsonii 3, Mycelis muralis 3, Neckera pennata 3, Pedinophyllum interruptum 3, Plagiochila porelloides 3, Pseudoleskeela catenulata 3, Schistidium sp. 3, Asplenium ruta-muraria 2, Adenostyles glabra 1, Anomodon attenuatus 1, Epilobium montanum 1, Neckera complanata 1, 


\section{Discussion}

\section{Niche assembly and ecology}

Campanula tommasiniana inhabits rock crevices that are remarkably diverse in the number of vascular plants and bryophytes. The number of coverage vascular plants vs. bryophytes varies substantially and depends much on microsite conditions; bryophytes prevail over vascular plants in fully shaded and moist microsites, e.g. in group of assemblages CfC (Cystopteridi-Campanuletum), while in open and exposed sites ( $\mathrm{SjC}-$ Seslerio juncifoliae-Campanuletum), vascular plants completely prevail over bryophytes. In our survey, one new bryophyte, Tortella densa, was recorded for Croatia for the first time and the finding was reported in detail elsewhere (SURINA and MARTINČIČ in ElLIS et al. 2012).

In comparable studies (but inferred from a different number of samples/relevés; bryophytes and lichens excluded) botanists found a considerably lower number of vascular plant taxa in niche assemblies of chasmophytic narrow endemics. For example: PignATTI and Pignatti (1978), for Campanula morettiana, restricted to the Italian Dolomites, in an elevational range between 1730-2450 m, recorded 38 taxa of vascular plants in 15 relevés (5-15 per rel., median=8), while the accompanying flora of geographically even more restricted Moehringia tommasinii (Caryophyllaceae) from northern Istria, in an elevational range between 150-360 m, numbers 32 taxa of vascular plants recorded in 9 relevés (4-13 per rel., median=11) (MARTINI 1990). However, in a detailed study on the phytosociological characteristics of the sites of Moehringia villosa (DAKSKOBLER 2000), restricted to the southern Julian Alps and the adjacent Prealps, 156 taxa of vascular plants in 88 relevés (5-30 per rel., median=15) sampled in an elevational range between 430-1830 m were recorded, which is comparable to the results of our study. Both Campanula tommasiniana and Moehringia villosa occupy rock crevices of relatively broad elevational range, forming floristically and ecologically well characterized but different syntaxa. According to the results of an extensive study (LAVERGNE et al. 2004), endemic taxa compared to widespread congeners differ in a number of ecological characteristics (their habitat in terms of abiotic and community characteristics) and biological traits (floral traits and the size and maternal fertility of individual plants), but not in levels of herbivory and levels of ecophysiological traits (specific leaf area, leaf dry matter content, leaf nitrogen concentration, and rates of photosynthesis). The principal component of the difference concerns the occurrence of endemic taxa in rocky and steep slopes in low, open habitats rather than forest vegetation (compare Grove and RACKHAM 2003, QuezÉL and MEDAIL 2003), with low species richness, regardless of geological bedrock. Highly specialized conditions in the physical environment select for these differences in small, ecologically and taxonomically isolated (endemic) populations, since rock crevices and screes experience a range of microclimatic conditions that are very different from both level rocky terrain and horizontal landscapes with soil. However, Campanula tommasiniana, despite being almost an obligate chasmophyte (see SURINA 2013), indicates a remarkable ability to adapt to various abiotic factors, but a relatively low number of taxa per microsite suggests low biotic competitiveness. In contrast to the similarly rich floristic assembly of Moehringia villosa, the niche assembly of Campanula tommasiniana constitutes only three taxa of vascular plants, all rockdwellers: Campanula tommasiniana, Asplenitum trichomanes, A. ruta-muraria), occurring in more than $50 \%$ of all samples, which additionally speaks for its high abiotic plasticity and niche differentiation. The most important ecological gradients in shaping the floristic assemblies are light 
conditions and moisture. According to field diagnostics, results of numerical and statistical analyses based on groups of characteristic and differential taxa among vascular plants, bryophytes as well as site ecology, three floristically and ecologically well defined groups of assemblages are identified. The assemblage $\mathrm{Sj}-\mathrm{C}$-Seslerio juncifoliae-Campanuletum is the most homogenous in terms of floristical composition, while the assemblage CfC Cystopteri-Campanuletum has the most uniform site ecology. This reflects also the life form spectrum, where chamaephytes, adapted to open sites, do not thrive at all in the assemblage Cysopteri-Campanuletum.

Our research proved the high diagnostic values of bryophytes for the delimitation of groups of assemblages based on floristic composition. Several taxa occur exclusively or almost exclusively in floristically and ecologically well differentiated groups of assemblages. However, their diagnostic values for site conditions are less significant, a fact already stressed and discussed by SuRINA and MARTINČıč (2012).

Results of our analyses suggest that Campanula tommasiniana is a chasmophyte of open and exposed habitats in the altimontane to subalpine vegetation belt, a similar niche preference (see HORVAT 1931) also for the closely related (see PARK et al. 2006, LIBER et al. 2008) but allopatric C. waldsteiniana, another endemic of the north-western Dinaric Alps.

Campanula tommasiniana experiences a range of microclimatic conditions along ecological gradients building three floristically and ecologically well defined and differentiated groups of chasmophytic assemblages, suggesting its high ecological plasticity and abiotic stress tolerance. Hence, the reason for its limited range, restricted to an area of 6-7 km², remains a puzzling question. Another stenoendemic, Hladnikia pastinacifolia (Apiaceae), a monotypic species with even narrower distribution area, restricted to a few localities of the Trnovski gozd plateau in north-western Dinaric Alps (MAYER 1960, ČUŠIN 2004), colonizes an even broader range of habitats - stony grasslands, rock crevices and screes (ŠAJNA et al. 2012), reflecting an ability to adapt to a variety of both abiotic and biotic factors. Nevertheless, $H$. pastinacifolia, like Campanula tommasiniana, remains confined to an extremely narrow distribution area, despite the many available habitats in the vicinity, also without any reasonable explanation.

\section{Nomenclatorial and synsystematic issues}

Stands with Campanula tommasiniana were first mentioned by HoRvaTić (1944), who recognized its diagnostic value and distinct floristic assemblages, naming the association Campanuletum tommasinianae Horvatić 1944. In the 1960s Horvatić mentioned and cited the association's name as Campanuletum tommasinianae-justinianae Horvatić 1960 (HoRVATIĆ 1960, 1963b). He found Campanula tommasiniana, C. justiniana, Hieracium bifidum and $H$. amplexicaule subsp. petraeum (recte H. bupleuroides) to be regionally characteristic taxa for the association occurring on calcareous cliffs and blocks within the thermophytic beech forests of the association Seslerio autumnalis-Fagetum. He classified it within the alliance Moehringion muscosae. To that end, TRINAJSTIĆ (2008) in his Plant Communities of Croatia, without giving a specific reason, found the valid publication for the association Horvatić's treatise from 1963. However, neither a supplementary analytical and/or synoptic table nor designation of a type relevé were provided, and both botanists failed to describe the association according to the rules of phytosociological nomenclature (compare WEBER et al. 2000). Beside purely nomenclatorial issues, our results show significantly more com- 
plex problems in syntaxonomics of communities with Campanula tommasiniana. Since three groups of assemblages are easily recognized, both floristically and ecologically, and even classified in two different alliances, we find the validation of the name and the description of additional syntaxa based on a sound association concept (WILLNER 2006), and following the rules of phytosociological nomenclature (WEBER et al. 2000), to be fully justified. While we find the differentiation and status of the newly described syntaxa not questionable, their syntaxonomic position within higher ranked syntaxa remains problematic. Hence our proposal is still only preliminary since it is evident that earlier attempts (e.g., HORVAT 1962, HoRVATIĆ 1963b, TRINAJSTIĆ 1980, TRINAJSTIĆ 2008) at stabilization of a chasmophytic syntaxonomic system in the northern Adriatic do not suffice, and therefore a thorough numerical revision is required.

\section{Acknowledgements}

Florijan Tomc and Filip Starčević (both Učka Nature Park, Liganj), Marko Randić (Public Institution »Priroda«, Rijeka) and Željka Modrić Surina (Natural History Museum Rijeka, Rijeka) helped substantially during the field work. Borut Kružić (Natural History Museum Rijeka, Rijeka) offered technical help in data digitalization. Igor Dakskobler (Institute of Biology, Science and Research Centre of the Slovenian Academy of Sciences and Arts, Ljubljana) helped with some literature data and gave plenty of advice in floristic data treatment, while Željka Modrić Surina, Antun Alegro and Toni Nikolić (both University of Zagreb, Faculty of Science, Department of Botany and the Botanical garden, Zagreb) commented on previous version of the manuscript. Many thanks to all of them. The research was financially supported by Učka Nature Park and Natural History Museum Rijeka (project no. 641-01/11-01/01, 2156/02-06-02/1-11-6).

\section{References}

Aeschimann, D., Lauber, K., Mosser, D. M., Theurillat, J.-P., 2004: Flora alpina. Band 1-3. Haupt Verlag, Bern, Stuttgart, Wien.

Blondel, J., Aronson, J. C., 1999: Biology and Wildlife of the Mediterranean Region. Oxford University Press, Oxford.

BraAk Ter, J. F. C., Šmilauer, P., 2002: CANOCO Reference Manual and CanoDraw for Windows. User's guide to Canoco for Windows: Software for Canonical Community Ordination (version 4.5). Microcomputer Power (Ithaca, NY, USA), New York.

BRANA, S., 2012: J. H. Zanichelli (1622-1729) and the first floristical investigations of Mt. Učka (in Croatian). In: Arko-PIJEvaC, M. Surina, B. (eds.), Natural history researches of the Rijeka region. II. Prirodoslovna biblioteka 15, 29-40. Prirodoslovni muzej Rijeka, Rijeka.

Braun-Blanquet, J., 1928: Pflanzensoziologie. Springer, Berlin.

ChYTRY, M., OTÝPKOVÁ, Z., 2003: Plot sizes used for phytosociological sampling of European vegetation. Journal of Vegetation Science 14, 563-570.

Curral, J. E. P., 1987: A transformation of the Domin scale. Plant Ecology 72, 81-87.

ČUŠIN, B., 2004: Hladnikia pastinacifolia Rchb. (in Slovenian). In: ČUŠIN, B. (ed.), NATURA 2000 in Slovenia. Vascular plants, 107-113. Založba ZRC, Ljubljana. 
DAHL, E., HADAČ, E., 1941: Strandgesellschaften der Insel Ostoy im Oslofjord. Eine pflanzensoziologische Studie. Nytt Magasin for Naturvidenskapene B 82, 251-312.

DAkskobler, I., 2000: Phytosociological characteristics of the sites of the endemic Moehringia villosa (Wulfen) Fenzl (Caryophyllaceae) (in Slovenian). Razprave IV. razreda SAZU 51, 41-93.

Düll, R., PAVletić, Z., MartinčIČ, A., 1999: Checklist of the Yugoslavian bryophytes. In: Düll, R., Ganeva, A., Martinčič, A., Pavletić, Z. (eds.), Contributions to the bryoflora of former Yugoslavia and Bulgaria, 1-94. IDH-Verlag, Bad Münstereifel.

Ellis, L. T., Alegro, A., Bednarek-Ochyra, H., Ochyra, R., Bergamini, A., Cogoni, A., Erzberger, P., Gorski, P., Gremmen, N., Hespanhol, H., Vieira, C., Kurbatova, L. E., Lebouvier, M., Martinčič, A., Asthana, A. K., Gupta, R., Nath, V., NatcheVa, R., Ganeva, A., Özdemir, T., Batan, N., Plašek, V., Porley, R. D., Randić, M., SAWicki, J., Schroder, V., Sergio, C., Smith, V. R., Sollman, P., Stefanut, S., Stevenson, C. R., Suarez, G. M., Surina, B., Uyar, G., Modrić Surina, Ž., 2012: New national and regional bryophyte records 31. Journal of Bryology 34, 123-134.

GAJIČ-ČAPKA, M., CINDRIĆ, K., MihaJlović, D., 2008: Precipitation. Climate atlas of Croatia 1961-1990. 1971-2000., 43-59. Državni hidrometeorološki zavod, Zagreb.

GinzBerger, A., 1921: Beitrag zur Kenntnis der Flora der Scoglien und kleineren Inseln Süd-Dalmatiens. Österreichische Botanische Zeitschrift 70, 233-248.

GinzBerger, A., Teyber, A., 1921: Über einige Centaurea-Arten der adriatischen Küsten und Inseln. II. Zur Kenntnis der Systematik und geographischen Verbreitung des Formenkreises von Centaurea Friderici Vis. und Centaurea crithmifolia Vis. Österreichische Botanische Zeitschrift 70, 29-46.

GomeZ-CAMPO, C., 1985: Plant conservation in the Mediterranean area. Dr. W. Junk, Dodrecht, Boston, Lancaster.

GREUTER, W., 1991: Botanical diversity, endemism, rarity and extinction in the Mediterranean area: an analysis based on the published volumes of Med-Checklist. Botanica Chronica 10, 63-79.

Grove, A. T., Rackham, O., 2003: The Nature of Mediterranean Europe. An Ecological History. Yale University Press, New Haven, London.

Hammer, O., Harper, D. A. T., Ryan, P. D., 2001: Paleontological Statistics Software Package for Education and Data Analysis. Palaeontologia Electronica 4, 1-9.

Hill, M. O., Preston, C. D., 1998: The geographical relationships of British and Irish bryophytes. Journal of Bryology 20, 127-226.

HoRvat, I., 1931: Vegetation studies in mountains of Croatia. II. Scree and rock-crevices communities (in Croatian). Rad Jugoslavenske akademije znanosti i umjetnosti 241, 147-206.

HoRvat, I., 1962: Mountain vegetation of west Croatia (in Croatian). Acta Biologica II 30, $1-179$.

HoRvatić, S., 1944: Plant life of Istria (in Croatian). Alma Mater Croatica 1-4, 45-56.

HoRvatić, S., 1960: Contribution to the knowledge of vegetation in southernl part of Primorje area in Croatia (in Croatian). Ljetopis Jugoslavenske akademije znanosti i umjetnosti 66, 302-308. 
HoRvatić, S., 1963a: Phytogeography and delimitation of Primorje area in the light of contemporary phytosociological research (in Croatian). Acta Botanica Croatica 22, $27-81$.

HoRvatić, S., 1963b: Vegetation map of the island of Pag with an overview of vegetation of the Primorje area (in Croatian). Prirodoslovna istraživanja 33, 1-187.

JANCHEN, E., 1910: Edraianthus-Arten der Balkanländer. Mitteilungen des Naturwissenschaftlichen Vereines an der Universität Wien 8, 1-40.

KoricA, B., 1975: Variabilité et écologie du complexe d' Asperula staliana. Phyton 17, 137-149.

KorICA, B., 1986: Endemic taxa of the Asperula staliana (Rubiaceae) agg. on Adriatic islands (in Croatian). Radovi Jugoslavenske akademije znanosti i umjetnosti 424, 357-400.

KovAČić, S., 2004: The genus Campanula L. (Campanulaceae) in Croatia, circum-Adriatic and west Balkan region. Acta Botanica Croatica 63, 171-202.

Lakušić, D., Rakić, T., Stefanović, S., Surina, B., Stevanović, V., 2009: Edraianthus x lakusicii (Campanulaceae) a new intersectional natural hybrid: morphological and molecular evidence. Plant Systematics and Evolution 280, 77-88.

Lavergne, S., Thompson, J. D., Garnier, E., Debussche, M., 2004: The biology and ecology of endemic and widespread plants: A comparative study of trait variation in 20 congeneric pairs. Oikos 107, 505-518.

LePŠ, J., ŠMilauer, P., 2003: Multivariate Analysis of Ecological Data using CANOCO. Cambridge University Press, Cambridge.

Liber, Z., KovačIĆ, S., NikOlić, T., Likić, S., RuŠAK, G., 2008: Relations between western Balkan endemic Campanula L. (Campanulaceae) lineages: Evidence from chloroplast DNA. Plant Biosystems 142, 40-50.

Lovrić, A. Ž., 1971: Sur la Centaurea kartschiana du Kvarner. Acta Botanica Croatica 30, $135-139$.

LovRIĆ, A. Ž., 1992: Biosystematics, endemism and sinecology of the genus Centaurea in the Primorje karst area (in Croatian). Bilten Ekologa 5, 101-106.

LOVRIĆ, A. Ž., KorICA, B., 1981: Adriatic endemics. 1. Speciation centers and origin of relics. Rapport Commission Internationale pour l'Exploration Scientifique de la Mer Méditerranée 27, 64-65.

MARTINČIČ, A., 1966: Elements of the Yugoslav bryoflora with remarks on their chorology and ecology (in Slovenian). Razprave IV razreda SAZU 9, 5-70.

MARTINČIČ, A., 2003: Annotated checklist of Sloveninan mosses (Bryopsida). Hacquetia 2, 91-166.

MARTINČIČ, A., 2011: Annotated checklist of Slovenian liverworts (Marchantiophyta) and hornworts (Anthocerotophyta). Scopolia 72, 1-38.

Martini, F., 1990: Distribution and Phytosociological Behaviour of Moehringia tommasinii March. Studia Geobotanica 10, 119-132.

MAYER, E., 1960: Südöstliches Alpenvorland - ein pflanzengeographisches Prachtgebiet. Jubiläumsjahrbuch des Ver.z.Schutz.d.Alpenfpflanzen und - Tiere 25, 1-9. 
MAYer, E., BLEČIĆ, V., 1969: Zur Taxonomie und Chorologie von Edraianthus sectio Uniflori. Phyton 13, 241-247.

Medail, F., Verlaque, V., 1997: Ecological characteristics and rarity of endemic plants from S. E. France and Corsica. Implications for biodiversity conservation. Biological Conservation 80, 269-281.

Müller-Dombois, D., Ellenberg, H., 1974: Aims and methods in vegetation ecology. John Wiley \& Sons, New York.

NARODNE NOVINE, 1999: Uredba o osnivanju Javne ustanove »Park prirode Učka« (NN 096/1999).

Park, J.-M., Kovačić, S., Liber, Z., Eddie, W. M. M., Schneeweiss, G. M., 2006: Phylogeny and Biogeography of Isophyllous Species of Campanula (Campanulaceae) in the Mediterranean Area. Systematic Botany 31, 862-880.

Pelcer, Z., 1983: Phytosociological characteristics of stands of bay Laurel in the areas of Istria and Kvarner (in Croatian). Zbornik radova Zbornika o Robertu Visianiju Šibenčaninu, Šibenik, 229-235.

PignAtTi, S., 2005: Valori di bioindicazione delle piante vascolari della flora d'Italia. Braun-Blanquetia 39, 1-97.

Pignatti, E., Pignatti, S., 1978: Über die Campanula morettiana - Vegetation in den Dolomiten. Poročila Vzhodnoalpsko-dinarskega društva za proučevanje vegetacije 14, 279-291.

QuezÉL, P., 1985: Definition of the Mediterranean region and origin of its flora. In: Gomez-CAmpo, C. (ed.), Plant conservation in the Mediterranean area, 9-24. Dr. W. Junk, Dordrecht.

QuezéL, P., MedaIL, F., 2003: Ecologie et biogéographie des forests du bassin méditerranéen. Elsevier, Paris.

RADIĆ, J., 1981: Endemic taxa of the genus Centaurea in Biokovo mountain range (in Croatian). Acta Biokovica 1, 71-145.

RAUNKIAER, C., 1907: Planterigets Livsformer og deres Betydning for Geografien. Gyldendalske Boghandel-Nordisk Forlag, Kobenhavn and Kristiania.

SuRINA, B., 2005: Subalpine and alpine vegetation of the Krn area in the Julian Alps (in Slovenian). Scopolia 57, 1-222.

Surina, B., MartinčIČ, A., 2012: Chasmopyhtes on screes? A rule and not an exception in the vegetation of the Karst (southwest Slovenia). Plant Biosystems 146, 1078-1091.

SuRINA, B. 2013: Discovery, updated distribution area and habitat preferences of Campanula tommasiniana, a narrow endemic of Mt Učka (Liburnian karst, north-western Adriatic). Natura Croatica 22, 171-180.

ŠAJna, N., Kavar, T., ŠušTar-Vozlič, J., Kaligarič, M., 2012: Population genetics of the narrow endemic Hladnikia pastinacifolia Rchb. (Apiaceae) indicates survival in siru during the Pleistocene. Acta Biologica Cracoviensia, Series Botanica 54, 1-13.

ŠIKIĆ, D., PlENIČAR, M., 1975: Supplement to geological map Ilirska Bistrica L 33-89 (in Croatian). Savezni geološki zavod, Beograd. 
ŠIKIĆ, D., PlenIČAR, M., ŠPARICA, M., 1967: Basic geological map 1:100000 L 33-89 Ilirska Bistrica. Institut za geološka istraživanja, Zagreb, Geološki zavod, Ljubljana, Zagreb.

ŠIKIĆ, D., PoLŠAK, A., 1973: Supplement to geological map Labin L 33-101 (in Croatian). Savezni geološki zavod, Beograd.

ŠIKIĆ, D., PolšAK, A., MaGAš, N., 1963: Basic geological map 1:100000 L 33-101 Labin. Institut za geološka istraživana Zagreb, Beograd.

ŠUGAR, I., 1970: Vegetation profile of Mt. Učka with the vegetation map of the area (in Croatian). Poročila Vzhodnoalpsko-dinarskega društva za proučevanje vegetacije 11, 213-218.

ŠUGAR, I., 1971: Mt. Učka - a new locality for edelweiss (Leontopodium alpinum Cass. var. krasense (Derg.) Hay.) in Croatia. Acta Botanica Croatica 30, 153-156.

ŠUGAR, I., 1984: New insights into the vegetation and phytogeography of the Istrian peninsula (in Croatian). Acta Botanica Croatica 43, 225-234.

TeYBER, A., 1913: Beitrag zur Flora Österreichs. Österreichische Botanische Zeitschrift 58, 486-493.

Topić, J., Nikolić, T., Vuković, N., 2009: Učka and Ćićarija (in Croatian). In: Nikolić, T., Topić, J., Vuković, N. (eds.), Importan plant areas in Croatia, 423-430. Prirodoslovno-matematički fakultet Sveučilišta u Zagrebu i Školska knjiga d.o.o., Zagreb.

TRINAJSTIĆ, I., 1980: Aperçu syntaxonomique de la vegetation des rochers de l'espace Adriatique. Studia Geobotanica 1, 203-212.

TRINAJSTIĆ, I., 2008: Plant communities of Croatia. Akademija šumarskih znanosti, Zagreb.

TRINAJSTIĆ, I., PAVLETIĆ, Z., 2012: History of botanical researches in the Croatian part of the Istrian peninsula (in Croatian). In: ArKo-PIJEvaC, M. SuRINA, B. (eds.), Natural history researches of the Rijeka region. II. Prirodoslovna biblioteka 15, 13-28. Prirodoslovni muzej Rijeka, Rijeka.

Trotter, A., 1912: Gli elementi Balcanico-Orientali della Flora Italiana e l'ipotesi dell' »Adriatide«. Atti del Reale Istituti d'incoraggiamento di Napoli.Serie VI. 9, 1-119.

Tutin, T. G., Heywood, V. H., Burges, N. A., Valentine, D. H., Walters, S. M., WebB, D. A., 2001: Flora Europaea on CD-ROM. Cambridge University Press, Cambridge.

Vukelić, J., 2012: Forest vegetation of Croatia (in Croatian). Sveučilište u Zagrebu, Šumarski fakultet, Državni zavod za zaštitu prirode, Zagreb.

Weber, H. E., Moravec, J., Theurillat, J.-P., 2000: International Code of Phytosociological Nomenclature. 3rd edition. Journal of Vegetation Science 11, 739-768.

WeSthoff, V., van DeR MAAREL, E., 1973: The Braun-Blanquet approach. In: WhitTAKER, R. H. (ed.), Ordination and Classification of Communities. Handbook of Vegetation Science 5., 619-726. Dr. W. Junk b.v.-Publishers, The Hague.

WetTsteIn, R., 1887: Monographie der Gattung Hedraeanthus. Denkschriften der kaiserlichen Akademie der Wissenschaften, mathematisch-naturwissenschaftliche Klasse 53, $185-212$.

WILLNER, W., 2006: The association concept revisited. Phytocoenologia 36, 67-76.

ZANINović, K., 2008: Air temperature. Climate atlas of Croatia 1961-1990. 1971-2000., 27-41. Državni hidrometeorološki zavod, Zagreb. 